\title{
Breast Cancer Brain Metastases: Clonal Evolution in Clinical Context
}

\author{
Jodi M. Saunus ${ }^{1,2, *}$, Amy E. McCart Reed ${ }^{1,2}$, Zhun Leong Lim ${ }^{1,2}$ and Sunil R. Lakhani 1,3,4 \\ 1 The University of Queensland (UQ), UQ Centre for Clinical Research, Herston, Queensland 4029, Australia; \\ amy.reed@uq.edu.au (A.E.M.R.); m.lim@uq.edu.au (Z.L.L.); s.lakhani@uq.edu.au (S.R.L.) \\ 2 QIMR Berghofer Medical Research Institute, Herston, Queensland 4006, Australia \\ 3 Pathology Queensland, Royal Brisbane Women's Hospital, Herston, Queensland 4029, Australia \\ 4 UQ School of Medicine, Herston, Queensland 4006, Australia \\ * Correspondence: j.saunus@uq.edu.au; Tel.: +61-7-3346-6030
}

Academic Editor: Dario Marchetti

Received: 8 November 2016; Accepted: 27 December 2016; Published: 13 January 2017

\begin{abstract}
Brain metastases are highly-evolved manifestations of breast cancer arising in a unique microenvironment, giving them exceptional adaptability in the face of new extrinsic pressures. The incidence is rising in line with population ageing, and use of newer therapies that stabilise metastatic disease burden with variable efficacy throughout the body. Historically, there has been a widely-held view that brain metastases do not respond to circulating therapeutics because the blood-brain-barrier (BBB) restricts their uptake. However, emerging data are beginning to paint a more complex picture where the brain acts as a sanctuary for dormant, subclinical proliferations that are initially protected by the BBB, but then exposed to dynamic selection pressures as tumours mature and vascular permeability increases. Here, we review key experimental approaches and landmark studies that have charted the genomic landscape of breast cancer brain metastases. These findings are contextualised with the factors impacting on clonal outgrowth in the brain: intrinsic breast tumour cell capabilities required for brain metastatic fitness, and the neural niche, which is initially hostile to invading cells but then engineered into a tumour-support vehicle by the successful minority. We also discuss how late detection, abnormal vascular perfusion and interstitial fluid dynamics underpin the recalcitrant clinical behaviour of brain metastases, and outline active clinical trials in the context of precision management.
\end{abstract}

Keywords: breast cancer; brain metastases; clonal evolution

\section{Clinico-Epidemiologic Profile of Brain Metastatic Breast Cancer}

Around $30 \%$ of breast cancer (BC) patients develop metastatic (stage IV) disease, and at least $15 \%$ will experience symptomatic relapse in the brain [1], a serious complication that causes rapid neurological decline and death in virtually all patients within a few years. Receiving this diagnosis marks a significant downturn for patients, both physiologically and psychologically. In addition to the personal burden, this is also a major socioeconomic problem because it often affects women who are members of the tax-paying workforce, are of childbearing age and/or have dependent children. The direct economic impact is also substantial, with the annual cost of care estimated to be $\sim \$ 100,000$ USD/patient in 2006, more than double stage IV patients without brain metastases (BM) [2]. Young age, high histologic grade, and tumour subtype are major risk factors [3,4].

$\mathrm{BM}$ are usually confirmed radiologically with magnetic resonance imaging (MRI), with or without gadolinium contrast enhancement, in patients who develop neurological symptoms (e.g., chronic headache, motor, cognitive or speech deficits, and seizures). Symptomatic treatment can include antiepileptic agents (e.g., phenytoin, levetiracetam) and also dexamethasone to control oedema 
and elevated intracranial pressure. Steroid treatment produces iatrogenic Cushing's syndrome and contributes to overall morbidity. Depending on the extent of disease, the patient's age and general health, local control measures can include surgical excision, stereotactic, and/or whole brain radiotherapy (SRS, WBRT). These modalities have been mainstays of treatment since the 1950s, and while their precision and efficacy are improving, ultimately they are not curative. For breast cancer brain metastases (BCBM), a combination of surgery and SRS seemed to provide the most benefit in an historic cohort, increasing median survival to 22 months compared to 5.5 months for WBRT [3].

There are currently no chemotherapeutic agents approved by the Federal Drug Administration (FDA) for management of BM. Our understanding of chemotherapy efficacy in different contexts is generally poor (particularly in relation to primary tumour histology and pre-treatment history), due to a lack of prospective clinical trials and drug uptake data. For example, depending on practice standards (which vary internationally and even between centres in the same country), chemotherapy is often given to patients with BM after local measures to control systemic disease, which apparently poses the most imminent health threat-multiple retrospective analyses have shown systemic disease burden is a poor prognostic indicator [5-7], and the presence of extracranial mets is a component of the Radiation Therapy Oncology Group's (RTOG) Graded Prognostic Assessment (GPA) tool [8,9]. In breast cancer, extracranial disease is present in $\sim 80 \%$ of patients with $\mathrm{BM}[10,11]$, but in contrast to earlier RTOG studies, recent meta-analyses found that extracranial disease is not prognostic after accounting for human epidermal growth factor receptor 2 (HER2) and hormone receptor status [3]. The rationale for chemotherapy treatment is not universal, and prospective data are urgently needed in a more contemporary setting to guide clinical decision-making [12].

An American study by Rosner et al. [13] originally demonstrated excellent (by today's standards) response rates to cytotoxics in 100 consecutive BCBM from a single institution between 1970 and $1985-52 \%-54 \%$ of patients treated with cyclophosphamide, fluorouracil, and prednisone, or methotrexate and vincristine, exhibited partial or complete central nervous system (CNS) responses assessed by computed tomography (CT) imaging. In 1992, Boogerd et al. reported a similarly encouraging response rate of $59 \%$ for patients treated with cyclophosphamide, methotrexate and 5-fluorouracil [6]. In contrast to these historic trials, agent selection is now often biased toward those predicted to penetrate the CNS, rather than those predicted to be most efficacious against metastatic breast cancer (expertly reviewed elsewhere [12]). There is evidence that the orally active 5 -fluoracil prodrug, capecitabine, is directly effective against BCBM-metabolites can be detected in $\mathrm{BM}$ surgical samples from $\mathrm{BC}$ patients given a single pre-operative dose [14], objective CNS responses to monotherapy have been observed in a small case series [15] and it enhances the clinical benefit of HER2-targeted therapy $[16,17]$.

\section{Breast Cancer Cell-Intrinsic Features Can Drive Breast Cancer Metastasis to the Brain}

The risk of developing BM is associated with primary tumour phenotype, highest for triple-negative (TN), HER2+, basal-like and claudin-low disease $[4,18,19]$. While systemic therapy is different between these groups, and obviously impacts BM development, in many cases the primary tumour has already seeded distant organs at the time of initial cancer diagnosis ('Fisher's theory' that cancer is a systemic disease at the time of diagnosis, which originally spurred the move away from radical mastectomy toward breast-conserving surgery with adjuvant treatment in the 1990s [20-22]). Micrometastases may also seed other organs (so-called 'self-seeding' [23,24]). Therefore, to some degree, brain metastatic fitness is (epi)genetically coded in the primary tumour, influenced by environmental and germline modifiers [25]. Specific examples of this include high expression of HER2, HER3, cyclooxygenase 2 (COX2), heparin-binding EGF-like growth factor (HB-EGF), neuroserpin, neurotrophin-3, and the glycosyltransferase ST6GALNAC5; and suppression of PTEN [26-31].

The requirements for initially colonising the brain are fundamentally different to those needed for sustained outgrowth, however some changes associated with risk of brain relapse have also been identified in BM surgical samples, implying a continuing requirement for outgrowth in the brain. 
For example, there are now robust data from independent studies showing that $E R B B 2$ over-expression and PTEN suppression in BM are underpinned by positive selection of hard-wired DNA copy-number alterations (CNAs) $[29,30]$. Other genes harbouring CNAs with corresponding changes in expression have recently been identified, but their significance remains to be elucidated. For example, the mitochondrial protein TMEM65 is amplified and overexpressed in $~ 50 \%$ of BM from breast and lung cancers, SOX11 is amplified and overexpressed in $\sim 30 \%$ of breast and $\sim 80 \%$ of lung cancer-BM, and NRG1 is lost and suppressed in $~ 60 \%$ of BCBM [29,32]. Large BC genome sequencing projects have not yet illuminated particular mutant alleles that bestow brain metastatic fitness, but hopefully these analyses will be forthcoming with the assembly of additional clinical data that includes site-specific relapse information.

Pre-programming of metastatic behaviour is also mediated systemically by tumour-derived microvesicles that circulate miRNA, mRNA and protein cargoes throughout the body. Exosome cargoes can prime pre-metastatic niches to receive circulating tumour cells (CTCs) and create a favourable niche for their outgrowth. Mechanistically this can involve vascular permeabilisation, angiogenesis, and extracellular matrix remodelling [33-35]. Molecular profiling of exosomes from brain-seeking cell lines have implicated particular miRNA and protein cargoes, but the clinical significance of these candidates is yet to be determined [36]. With the exception of elegant experiments showing that exosomes carrying integrin- $\beta 3$ can mediate brain-tropic behaviour [37], little is known about microvesicle specification of brain relapse. In particular, the field eagerly awaits technological developments that will facilitate microvesicle profiling from prospectively-collected patient blood samples.

$\mathrm{BM}$ are usually associated with extracranial metastases, particularly the liver, as the two are likely trapping sites for circulating tumour cells (CTCs), but $10 \%-17 \%$ of BM are not associated with extracranial disease [10,11,38] (significantly less frequent in African-American patients [39]). The relationship with clinical outcome is uncertain-brain-only-metastasis (BoM) has been associated with both poor and favourable survival relative to other patterns of disease spread [11,38]. Interestingly, BoM is not linked to HER2 or hormone receptor status [10], but is associated with expression of HER3 [27], which is the preferred oncogenic dimerization partner of HER2, and has ample access to neuregulin ligands in the brain [40-42]. Molecular profiling of BCs that exhibit BoM may identify new mechanisms and clinically informative biomarkers. Overall the frequency of BCs exhibiting BoM is only 14-25 for every 1000 cases, and so assembling a sample cohort to look for (epi)genetic features associated with this behaviour could be logistically challenging, however the clinical homogeneity in this group may enable molecular discoveries using a relatively small cohort.

\section{Extrinsic Factors That Drive Clonal Evolution in Brain Metastases}

\subsection{Microenvironment-Driven Selection Pressure}

The development of BM from CTCs is an incredibly complex process featuring continuous extrinsic selection pressure (depicted in Figure 1). This is initially driven by a requirement for CTCs to circumvent anoikis, tolerate shear stress in the circulation, then extravasate at distant sites, which ultimately favours cells most capable of co-opting the distant niche. Detailed analysis of BC patient CTC-derived cell lines implicated HER2, epidermal growth factor receptor (EGFR), heparanase (HPSE) and Notch1 in brain metastatic fitness [43]. Progression depends on actively crossing the blood-brain-barrier (BBB), the specialised vascular lining separating neural and vascular compartments of the central nervous system. The BBB features continuous tight junctions that oppose paracellular diffusion, diverting the passage of circulating metabolic substrates, xenobiotics, and other solutes to selective transcellular transport systems. Its function depends on contact between endothelia, the vascular-astroglial basement membrane, pericytes and the glia limitans, an interconnected layer of astrocyte foot processes that is key to neurovascular regulation [44]. Ultrastructural and immunofluorescent imaging data show that a fraction of CTCs arrest in capillaries or venules [45], and occasionally extend filopodia that mechanically push through the endothelium and adhere to the 
basement membrane [46-48]. Filopodia then dynamically extends and retracts into the parenchyma as cells migrate to a perivascular position [46,48]. Mediators of this process include specific adhesion molecules and proteases (e.g., integrins $\alpha 5, \beta 1, \beta 3$, cathepsin-S, matrix metalloproteinases (MMPs), and E-selectin [47,49-53]).

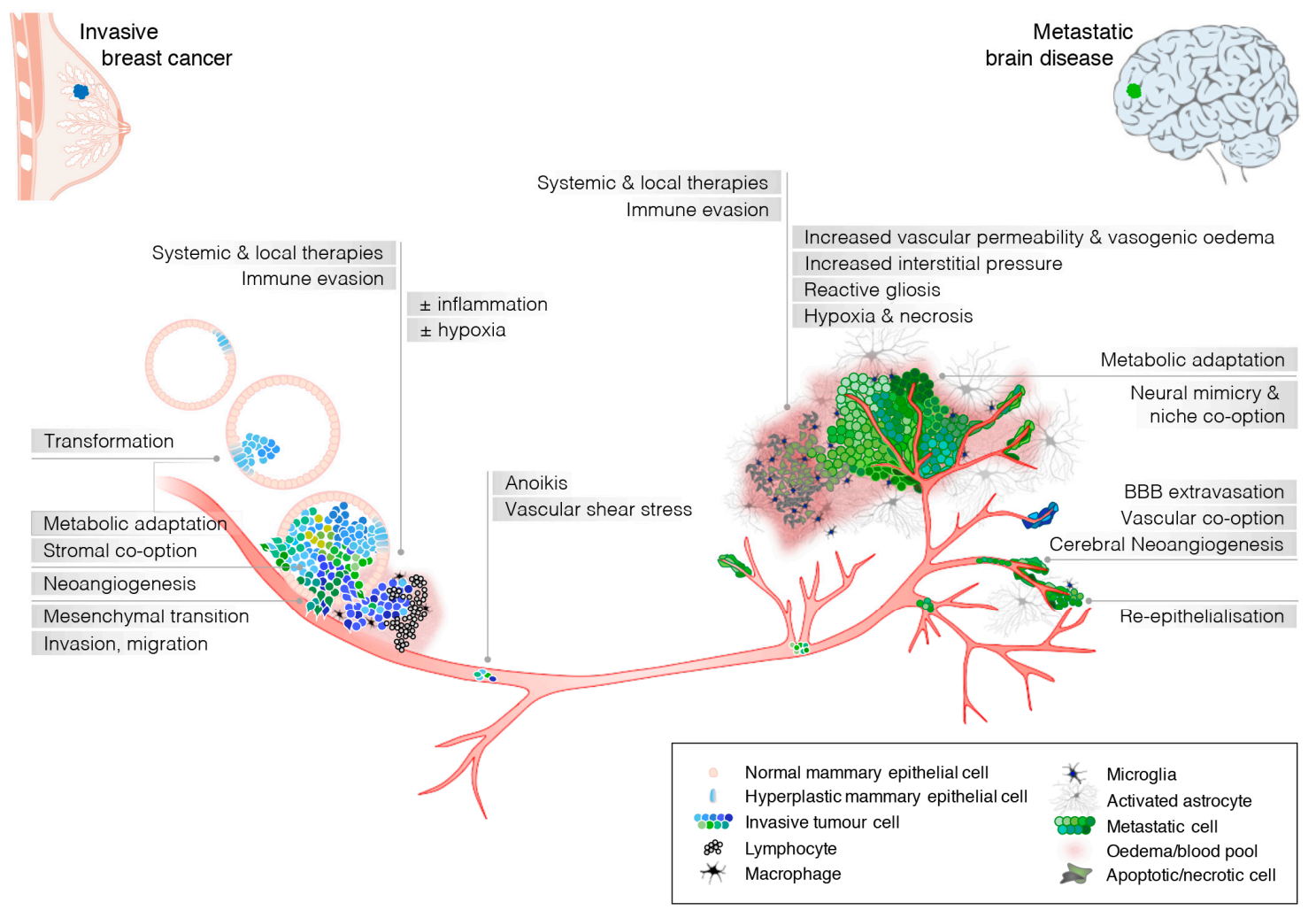

Figure 1. Schematic showing the breast cancer brain metastatic cascade; Requisite capabilities for metastatic fitness and extrinsic pressures driving clonal evolution are indicated in horizontal and vertical tracks, respectively.

The perivascular niche (PVN) is another critical point of tumour cell attrition-most are unable to tolerate the neuroinflammatory reaction that is rapidly instigated by microglia and astrocytes [28,45,48,54-61]. Cross-talk with resident pericytes and endothelia in the PVN seems to be key for tumour cell survival, quiescence, and therapeutic resistance-capabilities that underpin dormancy [62]. Further progression can take months or years depending on the evolutionary distance between BM-competent cells and their ancestors, and also their inherent adaptability. For example, aberrant DNA repair is common feature of BM, likely an adaptation to oxidative stress [63]. DNA repair is also defective in triple-negative breast cancer (TNBC), which relapses in the brain earlier than other subtypes [64], suggesting that pre-existing DNA repair defects could underlie rapid clinical progression. In terms of 'late metastasising' BCs, the anti-angiogenic glycoprotein thrombospondin-1, secreted by endothelia lining stable microvessels, has been linked to dormancy [62]. Inducing neo-angiogenesis could be a key milestone for tumours escaping dormancy, as endothelial tip cells are a source of tumour-promoting transforming growth factor $\beta 1$ (TGF- $\beta 1$ ) and periostin that seem to overcome the effects of thrombospondin. 
In order for micrometastases to progress, the initially hostile neural niche must be transformed into one that promotes colonisation, which essentially involves transforming the glial compartment into a tumour support engine [52,54,65-67]. Cells succeeding to this stage seem to migrate along paths of least resistance, dividing as they go. Some proliferate in the perivascular pathway, forming sheaths as they co-opt the vasculature; others prefer interstitial tracks and form well-demarcated parenchymal lesions $[28,68]$. These patterns co-exist in any given tumour at different proportions [69], but whether achieved by co-option or angiogenesis, vascular proximity is critical for outgrowth $[48,70]$.

Tumour cells use remarkable mechanisms to co-opt the neural niche. They cope with oxidative stress, repurpose neurotransmitters as metabolic substrates, recruit and promote the differentiation of neural progenitors into astrocyte support cells, mimic neural traits and effectively 'plug-and-play' with the new niche by inducing growth factor receptors (e.g., HER3, HER4, NTR3), particularly those that converge on the akt/PI3K/mTOR, mitogen-activated protein kinases (MAPK) and NF-kB $[27,29,54,63,65,71-73]$. Loss of the phosphoinositide 3-kinase (PI3K) inhibitor PTEN is one of the only recurrent genomic features identified to date [29,30,72], but a recent pioneering study by Zhang et al. [67] demonstrated that PTEN suppression can also occur as a reversible adaptation. They found that astrocyte-derived exosomes with cargoes from the miR-17/92 locus were able to silence PTEN in micrometastatic cells, which increased their secretion of microglia-activating C-C motif chemokine ligand 2 (CCL2) and promoted outgrowth [67].

\subsection{Therapy and Clonal Selection}

Historically, there has been a widely-held view that uptake of circulating drugs is severely limited by the BBB, since BM arise on a background of pre-treatment, and chemotherapeutics accumulate to sub-efficacious concentrations in experimental BM. For example, using fluorescence and phosphorescence brain imaging in intravenously xenografted mice and 4T1 syngeneic BM, Lockman et al. [74] found that vascular integrity was compromised in $89 \%$ of BM, but uptake of paclitaxel and doxorubicin was heterogeneous and up to 30-fold lower than extracranial tumours, reaching cytotoxic levels in just 10\% of the most permeable BM [74]. Analysis of lapatinib produced similar results, with variable and low uptake, and no evidence of intrinsic resistance in ex vivo BM cell cultures from treated mice [75]. However, the idea that insufficient uptake across the BBB is a universally limiting factor in human patients is at odds with several key lines of evidence. Firstly, detection of BM with contrast-enhanced MRI works on the basis that contrast agents move passively from the vascular space to the interstitium through vessel fenestrations, which occurs in BM larger than $\sim 5 \mathrm{~mm}$-so contrasting lesions are inherently 'leaky'. Secondly, CNS response rates of $>50 \%$ were observed in early chemotherapy trials [6,13], despite the use of hydrophilic agents that do not readily transverse intact vasculature, suggesting mouse models may not adequately recapitulate human BM tissue architecture or pharmacokinetic-pharmacodynamic determinants of drug efficacy. Finally, PET imaging studies have shown that large monoclonal antibodies (mAbs) accumulate in human BM to levels associated with efficacy at other sites [76-80], indicating that the treatment-refractory behaviour of BM is likely due to more than permeability alone [77]. Importantly, the distribution and cellular uptake of non-targeted therapies are passive and nonspecific, ultimately determined by each agent's molecular structure, fluid gradients, and rates of metabolism and clearance. Vascular perfusion, intracranial pressure and interstitial fluid dynamics are abnormal in BM, and collectively oppose passive drug diffusion (Section 5.2), whereas tumour-specific mAbs generally have longer half-lives and accumulate in tumour deposits. Studies correlating vascular permeability, fluid flow dynamics, tumour interstitial pressure and drug uptake in human BM would be very informative in terms of considering the impact of BM-specific physiologic factors on drug dosing and efficacy. 
We tend to relate clonal progression to clinical progression directly, on a patient or whole-tumour scale, but cycles of seeding, dormancy and regression are likely occurring simultaneously throughout the cerebrum on staggered timelines. BM arise from convergence of perivascular and interstitial proliferations, including index/parent lesions as well as the progeny of tumour self-seeding, all encased in reactive brain parenchyma $[55,81]$. As small lesions that were once fully protected behind an intact BBB become increasingly permeable, for a time they may be exposed to sub-efficacious drug concentrations, providing an ideal milieu for selection and outgrowth of resistant clones. In this context, another important consideration is that micrometastases may be effectively naïve to prior systemic therapy if protected behind an intact BBB segment at the time of initial treatment, and may respond to treatment once vascular permeability increases. Consistent with this idea, Boogerd et al. [6] reported clinical and objective CNS responses of $88 \%$ and $62 \%$ in a small cohort of BCBM patients treated with cytotoxic therapy in the late 1980s, including 100\% (7/7) and 70\% (5/7) who had previously been treated with the same regimens in the adjuvant setting or for progressive systemic disease [6].

Identifying the capabilities that are clonally selected in BM arising on a background of pre-treatment could inform the development of more holistic therapeutic strategies. For example, a landmark preclinical study from the Massagué team showed that protocadherin 7-expressing tumour cells form gap junctions with astrocytes, creating a feedback situation where cGAMP passed to astrocytes induce secretion of interferon $\alpha$ (IFN $\alpha$ ) and tumour necrosis factor (TNF). In turn, the cytokines act as paracrine factors that promote tumour growth and chemoresistance through signal transducer and activator of transcription 1 (STAT1) and NF- $\mathrm{KB}$ [61]. These findings prompted a clinical trial exploring the feasibility of using the gap junction modulator, meclofenamate, for BM treatment (Table 1). Another study assessing the efficacy of PI3K/mTOR therapy in HER2+ BM patient-derived xenografts $(\mathrm{PdX})$ found that non-responders exhibited higher genomic instability and defective DNA repair compared to responders [72], consistent with a separate report on mTOR treatment resistance [82]. These findings raise the possibility of using poly (ADP-ribose) polymerase (PARP) inhibitors to chemosensitise HER2+ BM with hypermutator phenotypes. There is also circumstantial evidence implicating HER3 in drug resistance-it is induced and activated in BM from breast and lung cancers, and has been separately implicated in resistance to anti-oestrogen, -HER2 and cytotoxic therapies [83-87]. Antibodies targeting HER3 (e.g., patritumab, AV-203, MM-121, AMG888, and HER2/3 bi-specifics) are currently being assessed for treatment of various solid cancers, though so far, not specifically BM. Molecular profiling of experimental or clinical samples representing pre- and post-therapy clonality and transcriptome profiles is urgently needed to identify additional candidates.

\section{The Molecular Portrait of Breast Cancer Brain Metastases}

An increasing number of studies are reporting high-resolution analysis of clinical and experimental samples to address biological questions and clinical challenges associated with BCBM. Key approaches, their strengths, limitations, and landmark findings are discussed below (Table 2). 
Table 1. Summary of current clinical trials of molecular-targeted agents for breast cancer patients with established brain metastases [88].

\begin{tabular}{|c|c|c|c|c|c|c|}
\hline NCT-ID & Subtype & Phase & Experimental Arm(s) & Comparator Arm & Approach & Primary Endpoints \\
\hline 02429570 & All & 0 & Meclofenamate & NA & GAP junction modulator & ORR, PFS, safety \\
\hline 01621906 & All & 0 & WBRT + Sorafenib $+[18$ F]FLT PET at baseline & WBRT + [18F]FLT PET at baseline & XRT + VEGFR & $\mathrm{RR}$ (radiographic) \\
\hline 01386580 & All & $1 / 2$ & Glutathione pegylated liposomal doxorubicin & Glutathione-pegylated liposomal dox + Trastuz & Carrier (CTx + HER2) & MTD, safety \\
\hline 01132664 & HER2+ & $1 / 2$ & Buparlisib + Trastuz & Buparlisib + Trastuz + Capecitabine & VEGFR + HER $2+$ CTx & MTD, RR, PFS, safety \\
\hline 02154529 & HER $2+$ & $1 / 2$ & Tesevatinib + Trastuz & Tesevatinib dose escalation + Trastuz & Broad-spec RTKi & MTD, PFS, RR, safety \\
\hline 01921335 & HER2+ & 1 & ARRY-380 + Trastuz & ARRY-380 dose escalation + Trastuz & HER2 & MTD, RR and PFS \\
\hline 01332929 & All & 1 & Bevacizumab + WRBT & Bevacizumab dose escalation + WRBT & XRT + VEGFR & MTD, RR, PFS \\
\hline 02598427 & HER2+ & 1 & Intrathecal Pertuzumab + Trastuz & Pertuzumab dose escalation + Trastuz & HER2 (CSF delivery) & MTD, safety \\
\hline 02650752 & HER2+ & 1 & Lapatinib + Capecitabine & Lapatinib dose escalation + Capecitabine & CTx + HER2 & MTD, RR, PFS \\
\hline 01276210 & All & 1 & Sorafenib tosylate + SRS & Sorafenib tosylate dose escalation + SRS & VEGFR + Raf kinase & MTD, RR, PFS \\
\hline 00981890 & All & 1 & Sunitinib + SRS & NA & XRT + VEGFR & Safety, MTD \\
\hline 00649207 & All & 1 & Veliparib + WBRT & Veliparib dose escalation + WBRT & PARPi & MTD, safety \\
\hline 01724606 & All & 1 & Sorafenib + WBRT & Sorafenib dose escalation + WBRT & XRT + VEGFR & MTD, safety \\
\hline 02308020 & All & 2 & Abemaciclib & NA & CDK4/6i & RR, PFS, safety \\
\hline 02768337 & All & 2 & Afatinib + 4 Gy XRT & Afatinib & $\mathrm{XRT}+\mathrm{HER} 2$ & Drug uptake \\
\hline 01441596 & HER2+ & 2 & Afatinib + vinorelbine & Afatinib & CTx + HER2 & PFS \\
\hline 02048059 & All & 2 & ANG1005 (formerly GRN1005) & NA & Carrier (CTx) & RR, PFS, OS \\
\hline 01898130 & All & 2 & Bevacizumab & NA & VEGFR + HER2 & RR, PFS, safety \\
\hline 02000882 & All & 2 & Buparlisib + Capecitabine (+Trastuz if HER2+) & NA & $\mathrm{CTx}+$ panPI3Ki & $\mathrm{RR}$ \\
\hline 01934894 & HER2+ & 2 & Cabazitaxel + Lapatinib & Cabazitaxel + Lapatinib (different doses) & CTx + HER2 & RR, MTD, safety \\
\hline 02260531 & All & 2 & Cabozantinib + Trastuz & Cabozantinib & c-met + VEGFR & RR, PFS, safety \\
\hline 02669914 & All & 2 & Durvalumab (MEDI4736) & NA & PDL1i & RR, PFS, safety \\
\hline 01305941 & HER2+ & 2 & Everolimus + Vinorelbine + Trastuz & NA & CTx + HER2 & RR, PFS, safety \\
\hline 01480583 & HER2+ & 2 & GRN1005 + Trastuz & GRN1005 alone & Carrier (CTx + HER2) & RR, PFS, safety \\
\hline 01494662 & HER2+ & 2 & Neratinib (HKI-272) & Neratinib (HKI-272) + Capecitabine & CTx + HER2 & RR, PFS, safety \\
\hline 01173497 & TNBC & 2 & Iniparib + Irinotecan & NA & CTx + PARPi & Efficacy, RR \\
\hline 01783756 & HER2+ & 2 & Lapatinib + Everolimus + Capecitabine & NA & $\mathrm{CT} x+\mathrm{HER} 2+\mathrm{mTORi}$ & RR, PFS, safety \\
\hline 01622868 & HER2+ & 2 & Lapatinib + WBRT or SRS & WBRT or SRS & XRT + HER2 & RR, PFS, safety \\
\hline 01218529 & All & 2 & Lapatinib + WRBT & NA & XRT + HER2 & $R R$ \\
\hline 02614794 & HER2+ & 2 & ONT-380 + Capecitabine + Trastuz & Placebo + Capecitabine + Trastuz & CTx + HER2 & PFS, RR, safety \\
\hline 02774681 & All & 2 & Palbociclib (+Trastuz if HER2+) & NA & CDK4/6i & RR (radiographic), PFS, safety \\
\hline 02312622 & All & 2 & Pegylated irinotecan (NKTR 102) & NA & Carrier (CTx) & Disease control rate, PFS \\
\hline 02536339 & HER2+ & 2 & Pertuzumab + Trastuz & NA & HER2 & RR, PFS, OS, safety \\
\hline 01924351 & HER2+ & 2 & SRS + HER-2 directed therapy & NA & XRT + HER2 & Relapse rate \\
\hline 02571530 & HER2+ & 2 & Intra-arterial cerebral infusion of Trastuz & May consider dose escalation & HER2 & MTD, OS, PFS \\
\hline 00303992 & HER2+ & 2 & Trastuz + Irinotecan & NA & CTx + HER2 & $R R$, disease progression \\
\hline 02185352 & All & 2 & WBRT + Bevacizumab, Etoposide, Cisplatin & WBRT alone & XRT + VEGFR & RR, PFS \\
\hline 00820222 & HER2+ & 3 & Lapatinib + Capecitabine & Trastuzumab + capecitabine & CTx + HER2 & PFS, RR \\
\hline 00073528 & ER/HER2+ & 3 & Lapatinib + Letrozole & Placebo + Letrozole & CTx (aromatase-i) + HER2 & RR, PFS, safety \\
\hline
\end{tabular}

CSF: cerebrospinal fluid; CTx: chemotherapy; i: inhibitor; MTD: maximum tolerated dose; NCT-ID: Clinical Trials.gov identifier; OS: overall survival; RR: response rate; PARP: poly (ADP-ribose) polymerase; PDL1: programmed death-ligand 1; PFS: progression-free survival; RTK: receptor tyrosine kinase; SRS: stereotactic radiosurgery; trastuz: trastuzumab; WBRT: whole brain radiotherapy; XRT: radiotherapy; [18F]FLT PET: 3-deoxy-3-18F-fluorothymidine positron emission tomography; HER2: human epidermal growth factor receptor 2; VEGFR: vascular endothelial growth factor receptor. 
Table 2. A catalogue of brain metastasis genomic studies.

\begin{tabular}{|c|c|c|c|c|c|c|c|c|c|c|c|}
\hline Study & $\begin{array}{l}\text { BCBM } \\
\text { Only? }\end{array}$ & $\begin{array}{l}\text { Matched } \\
\text { Pairs? }\end{array}$ & $\begin{array}{l}\text { Cohort } \\
\text { Size }\end{array}$ & FF or FFPE & GEX & CNA & $\begin{array}{l}\text { Mutation } \\
\text { Analysis }\end{array}$ & Exome & WGS & $\begin{array}{l}\text { Targeted or } \\
\text { Discovery }\end{array}$ & Key Findings \\
\hline Bos 2009 [89] & Yes & No & $1^{*}$ & $\mathrm{~F}$ & Array & No & No & No & No & D & $\begin{array}{l}\text { COX2, HBEGF (EGFR ligand), ST6GALNAC5 (a } \\
\text { 2,6-sialyltransferase) over-expressed, mediating BC cell passage } \\
\text { through the BBB, with ST6GALNAC5 expression enhancing BC } \\
\text { cell adhesion to brain endothelial cells }\end{array}$ \\
\hline $\begin{array}{l}\text { da Silva } 2010 \\
\text { [73] }\end{array}$ & No & Some & 78 & FFPE & $\begin{array}{l}\text { DASL (512 } \\
\text { genes) }\end{array}$ & No & OncoCarta & No & No & $\mathrm{T} / \mathrm{D}$ & $\begin{array}{l}\text { Over-expression of } \geq 1 \mathrm{HER} \text {, esp HER3 (relative to matched } \\
\text { primary tumours); Somatic mutations in EGFR, HRAS, KRAS, } \\
N R A S, \text { PIK } 3 C A ; \text { Increased activation of MAPK pathway in BM vs. } \\
\text { primary tumours }\end{array}$ \\
\hline $\begin{array}{l}\text { Ding } 2010 \\
\text { [90] }\end{array}$ & Yes & Yes & 1 & $\mathrm{FF}$ & No & SNP & No & No & Yes & D & $\begin{array}{l}\text { Matched peripheral blood, primary tumour, BM and PdX; BM: } \\
2 \text { private mutations, a large deletion, } 20 \text { enriched mutations } \\
\text { (PdX similar); } 2 \text { overlapping large deletions (CTNNA1) in all } \\
3 \text { tumour samples; Variation frequencies indicate metastases arise } \\
\text { from a minority of cells in the BC }\end{array}$ \\
\hline $\begin{array}{l}\text { Wikman } \\
2012[30]\end{array}$ & Yes & Some & 25 & FF & in silico & aCGH/AI & GSS & No & No & $\mathrm{T} / \mathrm{D}$ & $\begin{array}{l}9 \text { loci with significant differences, incl. EGFR amp (7p11.2) \& } \\
10 \mathrm{q} 22.3 \text {-qter loss; AI at PTEN more frequent in BM }(52 \%) \text { and brain } \\
\text { relapsing BC (59\%) compared with BC without relapse (18\%; } \\
p=0.003) \text { or relapse other than brain }(12 \% ; p=0.006) ; \text { Loss of } \\
\text { PTEN was especially frequent in HER2-negative BM (64\%); } \\
\text { PTEN mRNA was suppressed in BM compared with primary } \\
\text { tumours; PTEN mutations were frequently found in BM }\end{array}$ \\
\hline $\begin{array}{l}\text { McMullin } \\
2014[91]\end{array}$ & Yes & No & 19 & $\mathrm{FF}$ & Array & No & GSS & No & No & $\mathrm{T} / \mathrm{D}$ & $\begin{array}{l}\text { BRCA1 deficient-like GEX signature in HER2+ BCBM in absence of } \\
\text { BRCA1 mutations; Values significantly higher in HER2-/ER- vs. } \\
\text { HER2+/ER+ and HER2-/ER+ tumours }\end{array}$ \\
\hline $\begin{array}{l}\text { Salhia } 2014 \\
{[32]}\end{array}$ & Yes & No & 35 & $\mathrm{FF}$ & Array & $\mathrm{aCGH}^{\wedge}$ & No & No & No & D & $\begin{array}{l}\text { Frequent large gains 1q, 5p, 8q, 11q, 20q; broad-level deletions } \\
\text { (8p, 17p, 21p, Xq); ATAD2, BRAF, DERL1, DNMTRB and NEK2A } \\
\text { frequently amplified \& overexpressed; } A T M, C R Y A B \text { and HSPB2 } \\
\text { commonly deleted \& down-regulated Enrichment in cell cycle and } \\
\text { G2/M pathways (incl. AURKA, AURKB \& FOXM1; Defects in cell } \\
\text { migration and adhesion due to hypermethylation + suppression of } \\
\text { PENK, EDN3 and ITGAM; Hypomethylation + induction of KRT } \\
\text { likely affects adhesion and permeability }\end{array}$ \\
\hline $\begin{array}{l}\text { Bollig-Fischer } \\
\text { 2015 [92] }\end{array}$ & Yes & No & 10 & FF \& FFPE & No & aCGH & No & No & No & $\mathrm{T} / \mathrm{D}$ & $\begin{array}{l}\text { Stem cell pluripotency pathway enrichment; Recurring } \\
\text { amplification of } S O X 2 \text {, PIK3CA, NTRK1, GNAS, CTNNB1, \& FGFR1 }\end{array}$ \\
\hline $\begin{array}{c}\text { Brastianos } \\
2015[93]\end{array}$ & No & Yes & 86 & FF \& FFPE & No & No & No & Yes & No & D & $\begin{array}{l}86 \text { trios: matched BM, primary tumours, \& normal tissue } 53 \% \text { cases } \\
\text { had potentially clinically informative alterations in BM; Individual } \\
\text { BM deposits genetically homogenous; Distal extracranial and } \\
\text { regional node metastases highly divergent from BM; Alterations } \\
\text { associated with PI3K/AKT/mTOR, CDK, \& HER2/EGFRi } \\
\text { sensitivity in BM }\end{array}$ \\
\hline
\end{tabular}


Table 2. Cont.

\begin{tabular}{|c|c|c|c|c|c|c|c|c|c|c|c|}
\hline Study & $\begin{array}{l}\text { BCBM } \\
\text { Only? }\end{array}$ & $\begin{array}{c}\text { Matched } \\
\text { Pairs? }\end{array}$ & $\begin{array}{c}\text { Cohort } \\
\text { Size }\end{array}$ & FF or FFPE & GEX & CNA & $\begin{array}{l}\text { Mutation } \\
\text { Analysis }\end{array}$ & Exome & WGS & $\begin{array}{l}\text { Targeted or } \\
\text { Discovery }\end{array}$ & Key Findings \\
\hline Lee 2015 [94] & Yes & Some & 42 & FFPE & No & No & $\begin{array}{c}\text { Ion } \\
\text { Ampliseq } \\
\text { Cancer }\end{array}$ & No & No & $\mathrm{T}$ & $\begin{array}{l}\text { Frequent somatic mutations (e.g., TP53 59.5\%, MLH1 14.3\%, } \\
\text { PIK3CA } 14.3 \% \text {, KIT 7.1\%); No significant differences in mutation } \\
\text { profiles between BCBM and BC; TP53 mutation frequency higher } \\
\text { in BCBM than in primary BC ( } 59.5 \% \text { vs. } 38.9 \%)\end{array}$ \\
\hline $\begin{array}{c}\text { Saunus } 2015 \\
\text { [29] }\end{array}$ & No & No & 36 & FF & RNASeq & SNP & No & Yes & No & D & $\begin{array}{l}\text { Novel candidate genes: significantly mutated DSC2, ST7, PIK3R1 } \\
\text { and SMC5; DNA repair, HER signalling, axon guidance \& protein } \\
\text { kinase-A signalling pathways; Potentially actionable genomic } \\
\text { alterations in } 31 / 36 \text { BMs ( } 86 \% \text { ); Altered patient management } \\
\text { (+trastuz) in a case of HER2 status conversion; ERBB2 expression } \\
\text { correlated with ERBB3 ( } p<0.0001) \text {; HER3 \& HER4 frequently } \\
\text { activated in a cohort of } 167 \text { BM ( } 7 \text { primary cancer types); HER3 } \\
\text { ligands NRG1/2 barely detectable by RNAseq, with NRG1 (8p12) } \\
\text { genomic loss in } 63.6 \% \text { BCBM, suggesting a microenvironmental } \\
\text { source of ligand; Mutational signature analysis facilitated } \\
\text { identification of primary type for two CUP }\end{array}$ \\
\hline $\begin{array}{c}\text { Vareslija } 2015 \\
\text { [95] }\end{array}$ & Yes & Yes & 7 & U & RNASeq & No & No & No & No & D & $\begin{array}{l}\text { ER-specific metastatic pathways; Common pathways altered incl. } \\
\text { ECM, adhesion \& neuronal differentiation; ANTRX1, THBS2, FAP, } \\
V C A N \text { \& TIMP2 (invasion/migration/extravasation; } \\
\text { EMT/stemness signalling driven by ANTRX1; WNT-driven RUNX } \\
\text { prominent in cells acquiring migration ability }\end{array}$ \\
\hline Lee 2016 [96] & Yes & Some & 41 & FFPE & $\begin{array}{l}\text { Nanostring } \\
\text { (252 genes) }\end{array}$ & No & No & No & No & $\mathrm{T}$ & $\begin{array}{l}\text { 22/252 genes differentially expressed between BC and BCBM; } \\
\text { CXCL12, MMP2, MMP11, VCAM1 \& MME higher in BC, } \\
\text { SOX2 \& OLIG2 higher in BM; PAM50 molecular subtype } \\
\text { conversion observed in } 8 / 17 \text { pairs }(47.1 \%)\end{array}$ \\
\hline
\end{tabular}

* pleural effusion sample with subsequent in vivo selection for brain seeking derivatives; ^ study also performed whole genome methylation analysis using the Infinium Human Methylation 27 Bead Array; AI: allelic imbalance; BCBM: breast cancer brain metastasis; BM: Brain metastasis; CNA: copy-number alteration; CUP: cancer of unknown primary; DASL: cDNA-mediated annealing, selection, extension and ligation; ECM, extracellular matrix; FF: fresh-frozen; FFPE: formalin-fixed and paraffin-embedded; GEX: gene expression profiling; GSS: Gene Specific Sanger Sequencing; T: targeted; D: discovery; T/D: elements of both (i.e., study limited by panel, no alternate option at the time); U: unclear; WGS: whole genome sequencing. 


\subsection{Analysis of 'Brain-Seeking' Clonal Cell Line Derivatives}

To enrich for brain-tropic (epi)genomic traits, BC cell lines can be intravenously injected into experimental mice, developing BMs isolated, expanded in vitro, and subjected to successive in vivo passage cycles. Brain-tropic cell line derivatives have been applied in various ways, including the comparison to more heterogeneous parental cultures to identify genomic/transcriptomic traits associated with BM. Most commonly used are: the TNBC line, MDA-MB-231 and its brain-tropic derivative MDA-MB-231_Br; the syngeneic mouse 4T1.2 pair, also triple-negative; the BT-474 pair (HER2+) and HER2-overexpressing MDA-MB-231_Br cells, which produce BM of approximately three-fold greater size than the parental line $[63,74,89,97-99]$. While these lines don't fully recapitulate the phenotypic diversity of brain-tropic BC, they do provide functional experiments with greater relevance than lines derived from primary breast tumours or pleural effusions, and also guarantee higher take rates when generating experimental cohorts. Brain-seeking derivatives of five BC cell lines and the parental lines have been exome profiled [100], with little evidence found for a definitive genetic driver. Indeed, Jacob et al. [100] report that metastatic fitness can arise without de novo mutation, and can simply occur from further enrichment of particular mutant alleles.

The pioneering investigation of gene expression profiles in brain-seeking derivatives of two lines originally derived from TNBC pleural effusions (MDA-MB-231 and CN34) identified that COX2, HBEGF, and ST6GALNAC5 are enhancers of BBB extravasation [89]; COX2 and HBEGF, but not ST6GALNAC5, also likely function in extravasation in the lung. Interestingly, these genes were not differentially expressed in an independent cohort [101], nor could the role of ST6GALNAC5 in BBB extravasation be verified in a separate study [102]. There could be a technical or sampling-related basis for these discrepancies; for example, the independent studies exclusively analysed TNBCs while the original used unselected cases, and the BBB model was inherently different, comprising haematopoietic stem cell-derived endothelia and pericytes rather than umbilical vein endothelial cells and astrocytes.

These inconsistencies do, however, highlight some important limitations of model systems (extensively reviewed elsewhere [103]). As with any xenograft, a major limitation is that the brain-seeking system involves a mouse host supporting human cells in the absence of a full immune complement, a crucial impediment to the usual spread of cancer. On the other hand, syngeneic systems (e.g., 4T1.2) that model innate anti-tumour responses are also flawed because multiple aspects may not be representative of human biology/physiology. The in vitro expansion steps in between successive in vivo passages also impart a selection pressure not encountered in vivo, and intra-tumoural heterogeneity is reduced in these models. Nonetheless, brain-tropic cell lines are reproducible models amenable to controlled hypothesis testing, and are very important experimental tools for BM research.

\subsection{Analysis of Human Clinical Samples}

High-resolution molecular profiling of human tumours is essential to ensure relevance and make discoveries that lead to clinically translatable outcomes. Technological improvements have reduced the cost and vastly increased the volume and scale of cancer (epi)genome and transcriptome analysis. While The Cancer Genome Atlas (TCGA) and International Cancer Genome Consortium (ICGC) have made huge advances cataloguing BC genomes [104-106], currently they are not focussing on metastatic deposits. BM resection is not routinely performed and, thus, fresh frozen tissue samples are rare, however, prospectively collected cohorts are beginning to be sequenced by independent groups, and methodological advances are now allowing analysis of the lower quality, fragmented DNA and RNA from more accessible formalin-fixed, paraffin-embedded (FFPE) samples. Considering the vast cohort sizes and volumes of genomic data generated for primary BC [104-106], much of which is on the precipice of clinical translation, there is significant scope for extending the depth and breadth of (epi)genomic and transcriptomic analysis of BM.

A plethora of 'omics studies with small BM cohorts and/or targeted gene panels have emerged in the last few years (Table $1[30,32,91,92,94-96])$. Unsurprisingly, genes frequently altered in BC were 
also commonly detectable in BM, though mutant allele frequencies (MAF) for some were enriched in BM (e.g., TP53, PTEN, ATM) [30,32,94]. The high frequency of potentially actionable mutations identified supports implementation of BM diagnostic profiling to inform targeted therapy. Interestingly, a 'BRCA1-deficient-like' signature was identified in HER2+ BM with wild-type BRCA1, raising the possibility of using PARP inhibitors [91]. Indeed, inipirib and veliparib are being assessed clinically (Table 1). These trials are focusing on TNBC or unselected BC, but prospective assignment of HER2+ cases to PARPi therapy based on molecular profiling of any previously resected BM would be a rational next step to see whether the signature has predictive power in this group.

In terms of illuminating aspects of the biology, novel candidates have been identified in clinical sample discovery cohorts and validated, or are awaiting functional investigation in the field (Table 2). These include altered genes with corresponding changes in expression, functional gene networks with members collectively mutated more frequently than expected by chance, or that are differentially expressed between BM and matching primary tumours (Section 4.3). A unifying observation from the sequencing of primary tumour genomes is that cancer is underpinned by vast heterogeneity, with a seemingly infinite number of roads leading to Rome. However, in metastatic disease the distant 'host organ' is a common denominator, and so based on the idea that the neural niche may surpass intrinsic alterations in BM with different histologies and treatment histories, our group profiled the genomic and transcriptomic landscapes of BM from melanoma, lung, and breast cancers [29]. We integrated the data to identify recurrently altered, functionally-interconnected, gene networks (DNA repair, axon guidance, HER/ERBB and protein kinase-A signalling), and individual genes harbouring an unusually high number of expressed mutations that were predicted to be deleterious (e.g., DSC2, ST7, PIK3R1, SMC5).

The main limitations of using clinical samples in this way are, firstly, a lack of full control over other variables like patient age, germline modifiers, and treatment history. Secondly, sampling bias—profiling is usually performed on small pieces of larger tumours, which may not be representative of the whole tumour. Using larger amounts of tissue to circumvent sampling bias necessitates sequencing with more depth (thus more cost) in order detect subclonal alterations. Finally, clonal diversity reflects the growth requirements at the time of surgical excision, and so alterations that facilitate earlier stages of metastatic progression may be heavily diluted once selection pressure wanes-profiling human BM is essentially an endpoint analysis biased toward the latest stages of the metastatic cascade.

\subsection{Subtractive Analysis of Breast Cancer-Brain Met Pairs}

Comparative analysis of patient-matched pairs of primary tumour and normal tissue is essential to determine whether genetic variations are somatically acquired or inherited, and a 'trio' that also includes matching metastatic deposits is often considered the pinnacle for identifying metastasis-associated changes. In 2010, Ding et al. profiled the exomes and CNAs of a BM, primary tumour and a PdX model, and showed that BM are seeded from a minority of primary tumour cells [90]. The tumours were closely related, with 48/50 variants present in all three lesions. There was extensive heterogeneity in the primary, but a reduced MAF range in the $\mathrm{BM}$ and $\mathrm{PdX}$, reflecting the selection processes involved in metastatic progression. Brastianos et al. recently sequenced the exomes of 86 trios, achieving impressive statistical power for deep analysis of clonal selection [93]. The majority of cases exhibited branching evolution, with a 'trunk' of shared changes and a series of 'private' mutations reflecting continual independent evolution. Alterations predicting sensitivity to PI3K/AKT/mTOR, CDK and HER2/EGFR inhibitors were identified and, importantly, in 53\% of patients, these clinically informative or targetable mutations were not detected in the primary tumours. While extracranial disease deposits (e.g., lymph node mets, pleural effusions) may be more accessible for biopsy than BM, these were also highly divergent. These deep genomic data extend other findings from matched metastatic deposits (Table 2), which collectively indicate that management decisions should be based on BM diagnostic profiling wherever possible, rather than primary tumour or extracranial disease biomarkers. 
Matched clinical sample pairs are often only available as archival specimens, with severely fragmented RNA. However, specialised technologies have been successfully applied to identify candidate mediators of BM development. cDNA-mediated annealing, selection, extension and ligation (DASL) expression array profiling on 39 matched pairs revealed ERBB3 (HER3) and its adaptor protein GRB7 amongst genes most significantly induced in BM [73]. HER3 induction and activation have since been confirmed in independent, matched BM cohorts from breast and lung cancers, and unmatched BM from a wide range of primary cancer types, suggesting this is an adaptation of carcinoma cells to the neuregulin-rich microenvironment $[29,73,107,108]$. Others found that double-strand DNA damage repair genes (including BARD1 and RAD51) were over-represented in the BM compared to matching BCs [63], and in a third example, gene expression (GEX) profiling of eight BM compared to unpaired but clinically matched BC found that overexpression of hexokinase 2 (HK2) was associated with poor survival [109].

Anecdotally, there is often an expectation that identifying private alterations and differentially expressed genes will reveal the (epi)genetic history of metastatic disease and illuminate the biology underpinning progression, because the first studies of this kind were revolutionary (e.g., $[73,89,90])$, and according to classical scientific method, the most robust hypothesis testing involves test and control. However, even the ostensibly 'controlled' design of matched pair/trio studies is limited by unavoidable issues that confound interpretation of any tissue profiling experiment-sampling bias, and the 'endpoint' nature of the analysis. Notwithstanding the insights that subtractive approaches can provide into the biology involved, they discount candidates that may have important roles at both primary and metastatic sites, and the candidates identified are not necessarily clinically relevant, as primary BCs are usually successfully treated months or years before clinical presentation of brain disease.

\section{Factors Underlying the Recalcitrant Behaviour of Brain Metastases}

\subsection{Late Detection}

Currently, surgical stump recurrence is common because BM are poorly demarcated, excising a margin of normal brain tissue is not appropriate, and the residual cells that persist in the post-irradiation tissue environment are very pervasive [110]. There is an urgent need for effective molecular-targeted therapies to augment local control measures $[77,111]$, but prospective clinical data for established BM are lacking. This is largely because historically, a heavy co-morbidity burden and poor prognosis restricted participation of BM patients in clinical trials. Where they were included with no/minimal impact on intracranial disease progression, this was often interpreted as an overall lack of efficacy, yet we know that dosing is critical for achieving optimal delivery [112], and that the brain microenvironment impacts substantially on uptake and efficacy $[12,75,77,111]$. Some trials have assessed brain relapse as a secondary endpoint (e.g., [113]), though were essentially assessing prevention, or efficacy against small, asymptomatic BM with intact microvasculature. With time, modification to traditional clinical trial design $[114,115]$, and recognition that BM are not completely impenetrable to circulating agents, this trend is beginning to change (Table 1).

Recurrence also occurs at new sites in the brain. Deep exome sequencing has shown that, in any given patient, there is far less divergence amongst consecutive BM than between BM and matching primary or extracranial tumours [93], consistent with new lesions arising from stochastic awakening of dormant micrometastases, and/or self-seeding. Even synchronous BM that presented months apart were found to be close relatives despite treatment in the interim. This indicates that the next level of resistance was attained with minimal additional genomic change (through epigenomic or non-coding alterations not captured by exome sequencing); and perhaps also reflects that the requisite changes can be dynamic, reversible adaptations mediated via microenvironmental cross-talk $[67,116]$. It is becoming clear that the role of the brain microenvironment in driving therapeutic resistance has been severely underestimated [77,117]. For example, while neither trastuzumab \pm pertuzumab therapy 
reduces the incidence of $\mathrm{BM}$, these treatments delay $\mathrm{BM}$ development, reflecting a window of time in which resistant clones grow out after an initial debulking effect $[113,118]$.

In any case, by the time they are symptomatic and detected clinically, BM are essentially highly evolved manifestations of $B C$ that have already developed resistance to multiple lines of therapy, and can efficiently adapt to new extrinsic pressures. So long as they are identified at such a late stage, any treatment benefits will continue to be incremental [119] and yet, currently, diagnostic imaging is routinely performed on symptomatic patients and not for screening purposes. The risk of BM is increasing with improving systemic disease control $[2,113,118,120,121]$, indicating that micrometastases can develop into clinically significant BM if given time and opportunity. Critically, while $14 \%-15 \%$ of breast cancer patients develop symptomatic BM, evidence suggests they are actually far more prevalent-in a meta-analysis of CT/MRI data acquired to satisfy eligibility criteria for anti-angiogenic therapy trials in the late 1990s, Miller et al. found a roughly equal proportion of BC patients $(\sim 15 \%)$ had clinically occult BM [122]. Systematic histopathologic analyses of tissues taken at autopsy suggest the true incidence could be as high as 30\%-40\% [123-125]. Additionally, longitudinal imaging in mice has shown that micrometastases are substantially more prevalent than overt BM, while elegantly highlighting how mouse models can be applied to study metastatic dormancy (expertly reviewed elsewhere [126]). If metastatic screening is to be considered in the future to see if we can treat small and/or dormant lesions with curative intent, we need to couple the transition to precision cancer care with a search for reliable diagnostic imaging targets [127], develop clever conjugates that can cross the BBB to access small, dormant deposits with intact microvasculature, and develop prognostic markers to identify high-risk patients for whom metastatic screening is warranted.

\subsection{Abnormal Vascular Perfusion and Hypoxia Leads to Inadequate Drug Uptake and Therapeutic Resistance}

In the absence of adequate drug uptake data from human BM [14,128], animal modelling has led the field to coalesce on a view that while the BBB is leaky, it is not leaky enough to permit the uptake of systemic therapy to efficacious concentrations. While heterogeneous BBB permeability is most certainly one component of the clinical challenge, the situation is likely far more complex, with vasogenic oedema and elevated intracranial pressure also acting as critical determinants of drug bioavailability. Ongoing proliferation in solid tumours can fuel a perpetual cycle of hypoxia and unchecked neo-angiogenesis, creating chaotic, dysfunctional microvascular networks [129]. The constant vascular remodelling results in dyscoordinated vasoregulation, abnormal hydrostatic pressure gradients, and blood flow patterns, which, paradoxically, creates areas of sluggish blood flow and poor drug penetration in an otherwise hypervascularised environment $[45,129,130]$. These factors collectively underpin drug delivery challenges in BM, some of which are common to solid tumours, while others may be unique to the brain microenvironment.

Abnormal fluid dynamics also reduces drug efficacy because it leads to patchy hypoxia. Radiotherapy and certain cytotoxics act by generating reactive oxygen species that damage DNA, but strand breaks are more readily repairable in the absence of oxygen, allowing cells to escape fatal chromosome aberrations and, instead, erroneously repair DNA to increase genetic diversity. Hence, there are strong links between tumour hypoxia, cancer stem cell activity and chemo-/radio-resistance [131]. Indeed, BM are characterised by abnormal DNA repair, and hypermutator phenotypes have been associated with drug resistance in $\operatorname{PdX}$ of BM [63,72,91].

\section{Future Directions and Final Comments}

Given that inadequate and uneven delivery are critical factors limiting drug penetration, the field is beginning to explore alternative modes of delivery other than classic intravenous supply of naked compounds [132]. For example, several clinical trials are attempting to chemo/radiosensitise BM by targeting neoangiogenesis with VEGF signalling inhibitors (e.g., bevacizumab, sorafenib; Table 1). The intended effect of anti-angiogenic drugs was originally to starve tumours of oxygen but, in the context of combination regimens, blocking development of immature vessels may be beneficial 
because it reduces vascular tortuosity, normalises perfusion dynamics and increases oxygenation, thus enhancing drug delivery and the efficacy of DNA-damaging agents-the so-called 'vascular normalisation' effect $[129,133]$.

Other innovative approaches being investigated include carrier- or receptor-mediated drug transport across the BBB [132], and injected microbubbles that oscillate and permeabilise the BBB when energised using anatomically focused, MRI-guided ultrasound [134,135], which could improve drug bioavailability and improve immune recognition. Others are focusing on the development of multifunctional nanoconjugates designed to overcome multiple biological and physiological barriers before releasing their therapeutic payloads [136-138]. This is a very attractive concept for cancer therapy generally, but particularly for brain tumours where the BBB represents a unique challenge. Moreover, when it is not feasible to obtain a tissue biopsy to inform management decisions (e.g., high comorbidity burden, oligometastatic disease, or inoperable anatomical location), nanoconjugates could provide unprecedented theranostic capabilities [139].

In ancient Roman and Greek mythology, the Lernean Hydra was a serpentine water monster, raised by the goddess Hera to kill her illegitimate stepson and son of Zeus, Heracles. Hydra had toxic breath, multiple heads with venomous fangs, and grew new heads for every one severed by its opponents (Figure 2). In a way, this fable is a good analogy for metastatic brain disease, symbolising the perceived hopelessness of challenging an apparently immortal beast that becomes more empowered with every attempt to decapitate it. In the end, Hydra was defeated by Heracles, who used the serpent's own poisonous blood to burn each severed head so it could not regrow. Numerous strategies have been proposed to improve the clinical management of BC patients with metastatic brain disease, including prevention; better risk prediction and diagnosis of small, more manageable BM using molecular imaging; targeted drug delivery vectors, like nanoparticles; application of targeted agents to the neurosurgical cavity and externally activating sites of bioavailability to targeted drug conjugates (e.g., ultrasound BBB permeabilisation). Taking the Hydra analogy further, one idea gaining more support in the biomedical community is simultaneous targeting of tumour cell abnormalities and features of the neural niche on which growth and drug resistance depend [77,140,141]. Multiple studies have now verified the role of the metastatic brain tumour microenvironment in driving adaptation, outgrowth and drug resistance $[29,54,57,65-67,116]$. A noteworthy example of how these findings are being clinically translated is an ongoing meclofenamate feasibility study (a nonsteroidal anti-inflammatory drug (NSAID) traditionally used for treatment of pain, but which also inhibits gap junction gating). The community eagerly awaits similar examples in the future.

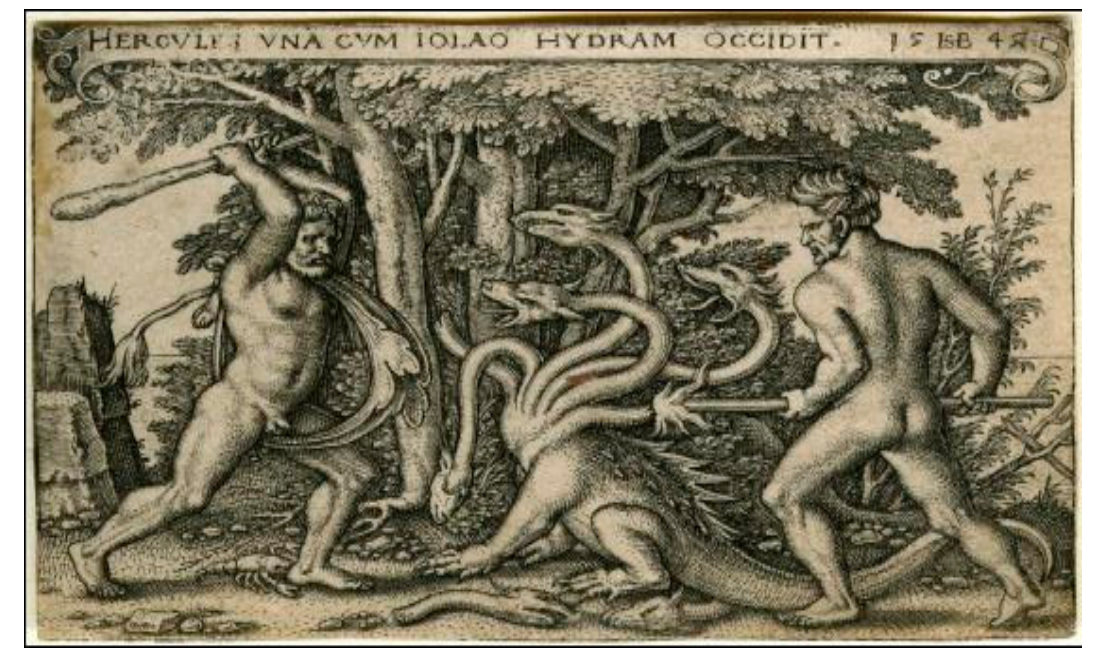

Figure 2. Depiction of the ancient Greek/Roman divine hero, Heracles, and his nephew (Iolaus) fighting the Hydra of Lerna, a serpentine water monster with heads that regenerated stronger and more numerous if severed [142]. 
Acknowledgments: Brain metastasis research is proceeding at phenomenal pace with an increasing volume of high-quality, relevant literature; We apologise to authors whose work we did not cover here due to space constraints; The authors are supported by funding from the Australian National Health and Medical Research Council, and the University of Queensland (APP1017028).

Author Contributions: Intellectual contributions: Jodi M. Saunus, Amy E. McCart Reed, Zhun Leong Lim, Sunil R. Lakhani, Zhun Leong Lim; literature surveys: Jodi M. Saunus, Amy E. McCart Reed, Zhun Leong Lim.

Conflicts of Interest: The authors declare no conflict of interest.

\section{References}

1. Witzel, I.; Oliveira-Ferrer, L.; Pantel, K.; Muller, V.; Wikman, H. Breast cancer brain metastases: Biology and new clinical perspectives. Breast Cancer Res. 2016, 18, 8. [PubMed]

2. Pelletier, E.M.; Shim, B.; Goodman, S.; Amonkar, M.M. Epidemiology and economic burden of brain metastases among patients with primary breast cancer: Results from a US claims data analysis. Breast Cancer Res. Treat. 2008, 108, 297-305. [CrossRef] [PubMed]

3. Sperduto, P.W.; Kased, N.; Roberge, D.; Xu, Z.; Shanley, R.; Luo, X.; Sneed, P.K.; Chao, S.T.; Weil, R.J.; Suh, J.; et al. Effect of tumor subtype on survival and the graded prognostic assessment for patients with breast cancer and brain metastases. Int. J. Radiat. Oncol. Biol. Phys. 2012, 82, 2111-2117. [CrossRef] [PubMed]

4. Berghoff, A.; Bago-Horvath, Z.; de Vries, C.; Dubsky, P.; Pluschnig, U.; Rudas, M.; Rottenfusser, A.; Knauer, M.; Eiter, H.; Fitzal, F.; et al. Brain metastases free survival differs between breast cancer subtypes. Br. J. Cancer 2012, 106, 440-446. [CrossRef] [PubMed]

5. Castaneda, C.A.; Flores, R.; Rojas, K.Y.; Castillo, M.; Dolores-Cerna, K.; Flores, C.; Belmar-Lopez, C.; Milla, E.; Gomez, H. Prognostic factors for patients with newly diagnosed brain metastasis from breast cancer. CNS Oncol. 2015, 4, 137-145. [CrossRef] [PubMed]

6. Boogerd, W.; Vos, V.W.; Hart, A.A.; Baris, G. Brain metastases in breast cancer; natural history, prognostic factors and outcome. J. Neurooncol. 1992, 15, 165-174. [CrossRef]

7. Berghoff, A.S.; Schur, S.; Fureder, L.M.; Gatterbauer, B.; Dieckmann, K.; Widhalm, G.; Hainfellner, J.; Zielinski, C.C.; Birner, P.; Bartsch, R.; et al. Descriptive statistical analysis of a real life cohort of 2419 patients with brain metastases of solid cancers. ESMO Open 2016, 1, 000024. [CrossRef] [PubMed]

8. Sperduto, P.W.; Berkey, B.; Gaspar, L.E.; Mehta, M.; Curran, W. A new prognostic index and comparison to three other indices for patients with brain metastases: An analysis of 1960 patients in the RTOG database. Int. J. Radiat. Oncol. Biol. Phys. 2008, 70, 510-514. [CrossRef] [PubMed]

9. Sperduto, P.W.; Chao, S.T.; Sneed, P.K.; Luo, X.; Suh, J.; Roberge, D.; Bhatt, A.; Jensen, A.W.; Brown, P.D.; Shih, H.; et al. Diagnosis-specific prognostic factors, indexes, and treatment outcomes for patients with newly diagnosed brain metastases: A multi-institutional analysis of 4259 patients. Int. J. Radiat. Oncol. Biol. Phys. 2010, 77, 655-661. [CrossRef] [PubMed]

10. Berghoff, A.S.; Bago-Horvath, Z.; Ilhan-Mutlu, A.; Magerle, M.; Dieckmann, K.; Marosi, C.; Birner, P.; Widhalm, G.; Steger, G.G.; Zielinski, C.C.; et al. Brain-only metastatic breast cancer is a distinct clinical entity characterised by favourable median overall survival time and a high rate of long-term survivors. Br. J. Cancer 2012, 107, 1454-1458. [CrossRef] [PubMed]

11. Nieder, C.; Oehlke, O.; Hintz, M.; Grosu, A.L. The challenge of durable brain control in patients with brain-only metastases from breast cancer. Springerplus 2015, 4, 585. [CrossRef] [PubMed]

12. Grimm, S.A. Treatment of brain metastases: Chemotherapy. Curr. Oncol. Rep. 2012, 14, 85-90. [CrossRef] [PubMed]

13. Rosner, D.; Nemoto, T.; Lane, W.W. Chemotherapy induces regression of brain metastases in breast carcinoma. Cancer 1986, 58, 832-839. [CrossRef]

14. Morikawa, A.; Peereboom, D.M.; Thorsheim, H.R.; Samala, R.; Balyan, R.; Murphy, C.G.; Lockman, P.R.; Simmons, A.; Weil, R.J.; Tabar, V.; et al. Capecitabine and lapatinib uptake in surgically resected brain metastases from metastatic breast cancer patients: A prospective study. Neuro Oncol. 2015, 17, 289-295. [CrossRef] [PubMed]

15. Ekenel, M.; Hormigo, A.M.; Peak, S.; Deangelis, L.M.; Abrey, L.E. Capecitabine therapy of central nervous system metastases from breast cancer. J. Neurooncol. 2007, 85, 223-227. [CrossRef] [PubMed] 
16. Lin, N.U.; Dieras, V.; Paul, D.; Lossignol, D.; Christodoulou, C.; Stemmler, H.J.; Roche, H.; Liu, M.C.; Greil, R.; Ciruelos, E.; et al. Multicenter phase II study of lapatinib in patients with brain metastases from HER2-positive breast cancer. Clin. Cancer Res. 2009, 15, 1452-1459. [CrossRef] [PubMed]

17. Lin, N.U.; Eierman, W.; Greil, R.; Campone, M.; Kaufman, B.; Steplewski, K.; Lane, S.R.; Zembryki, D.; Rubin, S.D.; Winer, E.P. Randomized phase II study of lapatinib plus capecitabine or lapatinib plus topotecan for patients with HER2-positive breast cancer brain metastases. J. Neurooncol. 2011, 105, 613-620. [CrossRef] [PubMed]

18. Fulford, L.G.; Reis-Filho, J.S.; Ryder, K.; Jones, C.; Gillett, C.E.; Hanby, A.; Easton, D.; Lakhani, S.R. Basal-like grade III invasive ductal carcinoma of the breast: Patterns of metastasis and long-term survival. Breast Cancer Res. 2007, 9, 4. [CrossRef] [PubMed]

19. Harrell, J.C.; Prat, A.; Parker, J.S.; Fan, C.; He, X.; Carey, L.; Anders, C.; Ewend, M.; Perou, C.M. Genomic analysis identifies unique signatures predictive of brain, lung, and liver relapse. Breast Cancer Res. Treat. 2011, 132, 523-535. [CrossRef] [PubMed]

20. Lu, Y.S.; Kuo, S.H.; Huang, C.S. Recent advances in the management of primary breast cancers. J. Formos. Med. Assoc. 2004, 103, 579-598. [PubMed]

21. Fisher, B.; Redmond, C.; Fisher, E.R.; Bauer, M.; Wolmark, N.; Wickerham, D.L.; Deutsch, M.; Montague, E.; Margolese, R.; Foster, R. Ten-year results of a randomized clinical trial comparing radical mastectomy and total mastectomy with or without radiation. N. Engl. J. Med. 1985, 312, 674-681. [CrossRef] [PubMed]

22. Fisher, B.; Jeong, J.H.; Anderson, S.; Bryant, J.; Fisher, E.R.; Wolmark, N. Twenty-five-year follow-up of a randomized trial comparing radical mastectomy, total mastectomy, and total mastectomy followed by irradiation. N. Engl. J. Med. 2002, 347, 567-575. [CrossRef] [PubMed]

23. Comen, E.; Norton, L. Self-seeding in cancer. Recent Results Cancer Res. 2012, 195, 13-23. [PubMed]

24. Norton, L.; Massague, J. Is cancer a disease of self-seeding? Nat. Med. 2006, 12, 875-878. [CrossRef] [PubMed]

25. Ren, Z.; Li, Y.; Hameed, O.; Siegal, G.P.; Wei, S. Prognostic factors in patients with metastatic breast cancer at the time of diagnosis. Pathol. Res. Pract. 2014, 210, 301-306. [CrossRef] [PubMed]

26. Muller, A.; Homey, B.; Soto, H.; Ge, N.; Catron, D.; Buchanan, M.E.; McClanahan, T.; Murphy, E.; Yuan, W.; Wagner, S.N.; et al. Involvement of chemokine receptors in breast cancer metastasis. Nature 2001, 410, 50-56. [CrossRef] [PubMed]

27. Berghoff, A.S.; Bartsch, R.; Preusser, M.; Ricken, G.; Steger, G.G.; Bago-Horvath, Z.; Rudas, M.; Streubel, B.; Dubsky, P.; Gnant, M.; et al. Co-overexpression of HER2/HER3 is a predictor of impaired survival in breast cancer patients. Breast 2014, 23, 637-643. [CrossRef] [PubMed]

28. Valiente, M.; Obenauf, A.C.; Jin, X.; Chen, Q.; Zhang, X.H.; Lee, D.J.; Chaft, J.E.; Kris, M.G.; Huse, J.T.; Brogi, E.; et al. Serpins promote cancer cell survival and vascular co-option in brain metastasis. Cell 2014, 156, 1002-1016. [CrossRef] [PubMed]

29. Saunus, J.M.; Quinn, M.C.; Patch, A.M.; Pearson, J.V.; Bailey, P.J.; Nones, K.; McCart Reed, A.E.; Miller, D.; Wilson, P.J.; Al-Ejeh, F.; et al. Integrated genomic and transcriptomic analysis of human brain metastases identifies alterations of potential clinical significance. J. Pathol. 2015, 237, 363-378. [CrossRef] [PubMed]

30. Wikman, H.; Lamszus, K.; Detels, N.; Uslar, L.; Wrage, M.; Benner, C.; Hohensee, I.; Ylstra, B.; Eylmann, K.; Zapatka, M.; et al. Relevance of PTEN loss in brain metastasis formation in breast cancer patients. Breast Cancer Res. 2012, 14, 49. [CrossRef] [PubMed]

31. Louie, E.; Chen, X.F.; Coomes, A.; Ji, K.; Tsirka, S.; Chen, E.I. Neurotrophin-3 modulates breast cancer cells and the microenvironment to promote the growth of breast cancer brain metastasis. Oncogene 2013, 32, 4064-4077. [CrossRef] [PubMed]

32. Salhia, B.; Kiefer, J.; Ross, J.T.; Metapally, R.; Martinez, R.A.; Johnson, K.N.; di Perna, D.M.; Paquette, K.M.; Jung, S.; Nasser, S.; et al. Integrated genomic and epigenomic analysis of breast cancer brain metastasis. PLoS ONE 2014, 9, 85448. [CrossRef] [PubMed]

33. Zhou, W.; Fong, M.Y.; Min, Y.; Somlo, G.; Liu, L.; Palomares, M.R.; Yu, Y.; Chow, A.; O'Connor, S.T.; Chin, A.R.; et al. Cancer-secreted miR-105 destroys vascular endothelial barriers to promote metastasis. Cancer Cell 2014, 25, 501-515. [CrossRef] [PubMed]

34. Chang, Q.; Bournazou, E.; Sansone, P.; Berishaj, M.; Gao, S.P.; Daly, L.; Wels, J.; Theilen, T.; Granitto, S.; Zhang, X.; et al. The IL-6/JAK/Stat3 feed-forward loop drives tumorigenesis and metastasis. Neoplasia 2013, 15, 848-862. [CrossRef] [PubMed] 
35. Syn, N.; Wang, L.; Sethi, G.; Thiery, J.-P.; Goh, B.-C. Exosome-Mediated Metastasis: From EpithelialMesenchymal Transition to Escape from Immunosurveillance. Trends Pharmacol. Sci. 2016, 37, 606-617. [CrossRef] [PubMed]

36. Camacho, L.; Guerrero, P.; Marchetti, D. MicroRNA and protein profiling of brain metastasis competent cell-derived exosomes. PLoS ONE 2013, 8, 73790. [CrossRef]

37. Hoshino, A.; Costa-Silva, B.; Shen, T.L.; Rodrigues, G.; Hashimoto, A.; Tesic Mark, M.; Molina, H.; Kohsaka, S.; di Giannatale, A.; Ceder, S.; et al. Tumour exosome integrins determine organotropic metastasis. Nature 2015, 527, 329-335. [CrossRef] [PubMed]

38. Ording, A.G.; Heide-Jorgensen, U.; Christiansen, C.F.; Norgaard, M.; Acquavella, J.; Sorensen, H.T. Site of metastasis and breast cancer mortality: A Danish nationwide registry-based cohort study. Clin. Exp. Metastasis 2016. [CrossRef] [PubMed]

39. Soni, A.; Ren, Z.; Hameed, O.; Chanda, D.; Morgan, C.J.; Siegal, G.P.; Wei, S. Breast cancer subtypes predispose the site of distant metastases. Am. J. Clin. Pathol. 2015, 143, 471-478. [CrossRef] [PubMed]

40. Bernstein, H.G.; Lendeckel, U.; Bertram, I.; Bukowska, A.; Kanakis, D.; Dobrowolny, H.; Stauch, R.; Krell, D.; Mawrin, C.; Budinger, E.; et al. Localization of NRG1 $\alpha$ and one of its receptors, ErbB-4 tyrosine kinase, in developing and adult human brain. Brain Res. Bull. 2006, 69, 546-559. [CrossRef] [PubMed]

41. Lok, J.; Sardi, S.P.; Guo, S.; Besancon, E.; Ha, D.M.; Rosell, A.; Kim, W.J.; Corfas, G.; Lo, E.H. Neuregulin-1 signaling in brain endothelial cells. J. Cereb. Blood Flow Metab. 2009, 29, 39-43. [CrossRef] [PubMed]

42. Pinkas-Kramarski, R.; Eilam, R.; Spiegler, O.; Lavi, S.; Liu, N.; Chang, D.; Wen, D.; Schwartz, M.; Yarden, Y. Brain neurons and glial cells express Neu differentiation factor/heregulin: A survival factor for astrocytes. Proc. Natl. Acad. Sci. USA 1994, 91, 9387-9391. [CrossRef] [PubMed]

43. Zhang, L.; Ridgway, L.D.; Wetzel, M.D.; Ngo, J.; Yin, W.; Kumar, D.; Goodman, J.C.; Groves, M.D.; Marchetti, D. The identification and characterization of breast cancer CTCs competent for brain metastasis. Sci. Transl. Med. 2013, 5, 180ra48. [CrossRef] [PubMed]

44. Alvarez, J.I.; Katayama, T.; Prat, A. Glial influence on the blood brain barrier. Glia 2013, 61, $1939-1958$. [CrossRef]

45. Kienast, Y.; von Baumgarten, L.; Fuhrmann, M.; Klinkert, W.E.; Goldbrunner, R.; Herms, J.; Winkler, F. Real-time imaging reveals the single steps of brain metastasis formation. Nat. Med. 2010, 16, 116-122. [CrossRef] [PubMed]

46. Kawaguchi, T.; Tobai, S.; Nakamura, K. Extravascular migration of tumor cells in the brain: An electron microscopic study. Invasion Metastasis 1982, 2, 40-50. [PubMed]

47. Carbonell, W.S.; Ansorge, O.; Sibson, N.; Muschel, R. The vascular basement membrane as "soil" in brain metastasis. PLoS ONE 2009, 4, 5857. [CrossRef] [PubMed]

48. Lorger, M.; Felding-Habermann, B. Capturing changes in the brain microenvironment during initial steps of breast cancer brain metastasis. Am. J. Pathol. 2010, 176, 2958-2971. [CrossRef] [PubMed]

49. Lee, T.H.; Avraham, H.K.; Jiang, S.; Avraham, S. Vascular endothelial growth factor modulates the transendothelial migration of MDA-MB-231 breast cancer cells through regulation of brain microvascular endothelial cell permeability. J. Biol. Chem. 2003, 278, 5277-5284. [CrossRef] [PubMed]

50. Lee, T.H.; Avraham, H.; Lee, S.H.; Avraham, S. Vascular endothelial growth factor modulates neutrophil transendothelial migration via up-regulation of interleukin-8 in human brain microvascular endothelial cells. J. Biol. Chem. 2002, 277, 10445-10451. [CrossRef] [PubMed]

51. Kang, S.A.; Hasan, N.; Mann, A.P.; Zheng, W.; Zhao, L.; Morris, L.; Zhu, W.; Zhao, Y.D.; Suh, K.S.; Dooley, W.C.; et al. Blocking the adhesion cascade at the premetastatic niche for prevention of breast cancer metastasis. Mol. Ther. 2015, 23, 1044-1054. [CrossRef] [PubMed]

52. Sevenich, L.; Bowman, R.L.; Mason, S.D.; Quail, D.F.; Rapaport, F.; Elie, B.T.; Brogi, E.; Brastianos, P.K.; Hahn, W.C.; Holsinger, L.J.; et al. Analysis of tumour- and stroma-supplied proteolytic networks reveals a brain-metastasis-promoting role for cathepsin S. Nat. Cell Biol. 2014, 16, 876-888. [CrossRef] [PubMed]

53. Momeny, M.; Saunus, J.M.; Marturana, F.; McCart Reed, A.E.; Black, D.; Sala, G.; Iacobelli, S.; Holland, J.D.; Yu, D.; da Silva, L.; et al. Heregulin-HER3-HER2 signaling promotes matrix metalloproteinase-dependent blood-brain-barrier transendothelial migration of human breast cancer cell lines. Oncotarget 2015, 6, 3932-3946. [CrossRef] [PubMed] 
54. Neman, J.; Choy, C.; Kowolik, C.M.; Anderson, A.; Duenas, V.J.; Waliany, S.; Chen, B.T.; Chen, M.Y.; Jandial, R. Co-evolution of breast-to-brain metastasis and neural progenitor cells. Clin. Exp. Metastasis 2013, 30, 753-768. [CrossRef] [PubMed]

55. Steeg, P.S.; Camphausen, K.A.; Smith, Q.R. Brain metastases as preventive and therapeutic targets. Nat. Rev. Cancer 2011, 11, 352-363. [CrossRef] [PubMed]

56. Baeten, K.M.; Akassoglou, K. Extracellular Matrix and Matrix Receptors in Blood-Brain Barrier Formation and Stroke. Dev. Neurobiol. 2011, 1013-1039. [CrossRef] [PubMed]

57. Termini, J.; Neman, J.; Jandial, R. Role of the neural niche in brain metastatic cancer. Cancer Res. 2014, 74, 4011-4015. [CrossRef] [PubMed]

58. Zhang, C.; Yu, D. Microenvironment determinants of brain metastasis. Cell Biosci. 2011, 1, 8. [CrossRef] [PubMed]

59. Heyn, C.; Ronald, J.A.; Ramadan, S.S.; Snir, J.A.; Barry, A.M.; MacKenzie, L.T.; Mikulis, D.J.; Palmieri, D.; Bronder, J.L.; Steeg, P.S.; et al. In vivo MRI of cancer cell fate at the single-cell level in a mouse model of breast cancer metastasis to the brain. Magn. Reson. Med. 2006, 56, 1001-1010. [CrossRef] [PubMed]

60. Chuang, H.N.; van Rossum, D.; Sieger, D.; Siam, L.; Klemm, F.; Bleckmann, A.; Bayerlova, M.; Farhat, K.; Scheffel, J.; Schulz, M.; et al. Carcinoma cells misuse the host tissue damage response to invade the brain. Glia 2013, 61, 1331-1346. [CrossRef] [PubMed]

61. Chen, Q.; Boire, A.; Jin, X.; Valiente, M.; Er, E.E.; Lopez-Soto, A.; Jacob, L.S.; Patwa, R.; Shah, H.; Xu, K.; et al. Carcinoma-astrocyte gap junctions promote brain metastasis by cGAMP transfer. Nature 2016, 533, 493-498. [CrossRef] [PubMed]

62. Ghajar, C.M.; Peinado, H.; Mori, H.; Matei, I.R.; Evason, K.J.; Brazier, H.; Almeida, D.; Koller, A.; Hajjar, K.A.; Stainier, D.Y.; et al. The perivascular niche regulates breast tumour dormancy. Nat. Cell Biol. 2013, 15, 807-817. [CrossRef] [PubMed]

63. Woditschka, S.; Evans, L.; Duchnowska, R.; Reed, L.T.; Palmieri, D.; Qian, Y.; Badve, S.; Sledge, G., Jr.; Gril, B.; Aladjem, M.I.; et al. DNA double-strand break repair genes and oxidative damage in brain metastasis of breast cancer. J. Natl. Cancer Inst. 2014, 106, 145. [CrossRef] [PubMed]

64. Niikura, N.; Hayashi, N.; Masuda, N.; Takashima, S.; Nakamura, R.; Watanabe, K.; Kanbayashi, C.; Ishida, M.; Hozumi, Y.; Tsuneizumi, M.; et al. Treatment outcomes and prognostic factors for patients with brain metastases from breast cancer of each subtype: A multicenter retrospective analysis. Breast Cancer Res. Treat. 2014, 147, 103-112. [CrossRef] [PubMed]

65. Neman, J.; Termini, J.; Wilczynski, S.; Vaidehi, N.; Choy, C.; Kowolik, C.M.; Li, H.; Hambrecht, A.C.; Roberts, E.; Jandial, R. Human breast cancer metastases to the brain display GABAergic properties in the neural niche. Proc. Natl. Acad. Sci. USA 2014, 111, 984-989. [CrossRef] [PubMed]

66. Gril, B.; Palmieri, D.; Qian, Y.; Anwar, T.; Liewehr, D.J.; Steinberg, S.M.; Andreu, Z.; Masana, D.; Fernandez, P.; Steeg, P.S.; et al. Pazopanib inhibits the activation of PDGFRbeta-expressing astrocytes in the brain metastatic microenvironment of breast cancer cells. Am. J. Pathol. 2013, 182, 2368-2379. [CrossRef] [PubMed]

67. Zhang, L.; Zhang, S.; Yao, J.; Lowery, F.J.; Zhang, Q.; Huang, W.C.; Li, P.; Li, M.; Wang, X.; Zhang, C.; et al. Microenvironment-induced PTEN loss by exosomal microRNA primes brain metastasis outgrowth. Nature 2015, 527, 100-104. [CrossRef] [PubMed]

68. Gritsenko, P.G.; Ilina, O.; Friedl, P. Interstitial guidance of cancer invasion. J. Pathol. 2012, 226, $185-199$. [CrossRef] [PubMed]

69. Berghoff, A.S.; Rajky, O.; Winkler, F.; Bartsch, R.; Furtner, J.; Hainfellner, J.A.; Goodman, S.L.; Weller, M.; Schittenhelm, J.; Preusser, M. Invasion patterns in brain metastases of solid cancers. Neuro Oncol. 2013, 15, 1664-1672. [CrossRef] [PubMed]

70. Fidler, I.J.; Yano, S.; Zhang, R.D.; Fujimaki, T.; Bucana, C.D. The seed and soil hypothesis: Vascularisation and brain metastases. Lancet Oncol. 2002, 3, 53-57. [CrossRef]

71. Chen, E.I.; Hewel, J.; Krueger, J.S.; Tiraby, C.; Weber, M.R.; Kralli, A.; Becker, K.; Yates, J.R., 3rd; Felding-Habermann, B. Adaptation of energy metabolism in breast cancer brain metastases. Cancer Res. 2007, 67, 1472-1486. [CrossRef] [PubMed]

72. Ni, J.; Ramkissoon, S.H.; Xie, S.; Goel, S.; Stover, D.G.; Guo, H.; Luu, V.; Marco, E.; Ramkissoon, L.A.; Kang, Y.J.; et al. Combination inhibition of PI3K and mTORC1 yields durable remissions in mice bearing orthotopic patient-derived xenografts of HER2-positive breast cancer brain metastases. Nat. Med. 2016, 22, 723-726. [CrossRef] [PubMed] 
73. Da Silva, L.; Simpson, P.T.; Smart, C.E.; Cocciardi, S.; Waddell, N.; Lane, A.; Morrison, B.J.; Vargas, A.; Healey, S.; Beesley, J.; et al. HER3 and downstream pathways are involved in colonization of brain metastases from breast cancer. Breast Cancer Res. 2010, 12, 46. [CrossRef] [PubMed]

74. Lockman, P.R.; Mittapalli, R.K.; Taskar, K.S.; Rudraraju, V.; Gril, B.; Bohn, K.A.; Adkins, C.E.; Roberts, A.; Thorsheim, H.R.; Gaasch, J.A.; et al. Heterogeneous blood-tumor barrier permeability determines drug efficacy in experimental brain metastases of breast cancer. Clin. Cancer Res. 2010, 16, 5664-5678. [CrossRef] [PubMed]

75. Taskar, K.S.; Rudraraju, V.; Mittapalli, R.K.; Samala, R.; Thorsheim, H.R.; Lockman, J.; Gril, B.; Hua, E.; Palmieri, D.; Polli, J.W.; et al. Lapatinib Distribution in HER2 Overexpressing Experimental Brain Metastases of Breast Cancer. Pharm. Res. 2012, 29, 770-781. [CrossRef] [PubMed]

76. Dijkers, E.C.; Oude Munnink, T.H.; Kosterink, J.G.; Brouwers, A.H.; Jager, P.L.; de Jong, J.R.; van Dongen, G.A.; Schroder, C.P.; Lub-de Hooge, M.N.; de Vries, E.G. Biodistribution of 89Zr-trastuzumab and PET imaging of HER2-positive lesions in patients with metastatic breast cancer. Clin. Pharmacol. Ther. 2010, 87, 586-592. [CrossRef] [PubMed]

77. Kodack, D.P.; Askoxylakis, V.; Ferraro, G.B.; Fukumura, D.; Jain, R.K. Emerging Strategies for Treating Brain Metastases from Breast Cancer. Cancer Cell 2015, 27, 163-175. [CrossRef] [PubMed]

78. Laforest, R.; Lapi, S.E.; Oyama, R.; Bose, R.; Tabchy, A.; Marquez-Nostra, B.V.; Burkemper, J.; Wright, B.D.; Frye, J.; Frye, S.; et al. [89Zr]Trastuzumab: Evaluation of Radiation Dosimetry, Safety, and Optimal Imaging Parameters in Women with HER2-Positive Breast Cancer. Mol. Imaging Biol. 2016, 18, 952-959. [CrossRef] [PubMed]

79. Mortimer, J.E.; Bading, J.R.; Colcher, D.M.; Conti, P.S.; Frankel, P.H.; Carroll, M.I.; Tong, S.; Poku, E.; Miles, J.K.; Shively, J.E.; et al. Functional imaging of HER2-positive metastatic breast cancer using (64)Cu-DOTA-trastuzumab PET. J. Nucl. Med. 2014, 55, 23-29. [CrossRef] [PubMed]

80. Tamura, K.; Kurihara, H.; Yonemori, K.; Tsuda, H.; Suzuki, J.; Kono, Y.; Honda, N.; Kodaira, M.; Yamamoto, H.; Yunokawa, M.; et al. 64Cu-DOTA-trastuzumab PET imaging in patients with HER2-positive breast cancer. J. Nucl. Med. 2013, 54, 1869-1875. [CrossRef] [PubMed]

81. Saito, N.; Hatori, T.; Murata, N.; Zhang, Z.A.; Ishikawa, F.; Nonaka, H.; Iwabuchi, S.; Samejima, H. A double three-step theory of brain metastasis in mice: The role of the pia mater and matrix metalloproteinases. Neuropathol. Appl. Neurobiol. 2007, 33, 288-298. [CrossRef] [PubMed]

82. Hortobagyi, G.N.; Chen, D.; Piccart, M.; Rugo, H.S.; Burris, H.A., 3rd; Pritchard, K.I.; Campone, M.; Noguchi, S.; Perez, A.T.; Deleu, I.; et al. Correlative Analysis of Genetic Alterations and Everolimus Benefit in Hormone Receptor-Positive, Human Epidermal Growth Factor Receptor 2-Negative Advanced Breast Cancer: Results From BOLERO-2. J. Clin. Oncol. 2016, 34, 419-426. [PubMed]

83. Garrett, J.T.; Olivares, M.G.; Rinehart, C.; Granja-Ingram, N.D.; Sanchez, V.; Chakrabarty, A.; Dave, B.; Cook, R.S.; Pao, W.; McKinely, E.; et al. Transcriptional and posttranslational up-regulation of HER3 (ErbB3) compensates for inhibition of the HER2 tyrosine kinase. Proc. Natl. Acad. Sci. USA 2011, 108, 5021-5026. [CrossRef]

84. Sergina, N.V.; Rausch, M.; Wang, D.; Blair, J.; Hann, B.; Shokat, K.M.; Moasser, M.M. Escape from HER-family tyrosine kinase inhibitor therapy by the kinase-inactive HER3. Nature 2007, 445, 437-441. [CrossRef] [PubMed]

85. Ma, J.; Lyu, H.; Huang, J.; Liu, B. Targeting of erbB3 receptor to overcome resistance in cancer treatment. Mol. Cancer 2014, 13, 105. [CrossRef] [PubMed]

86. Morrison, M.M.; Hutchinson, K.; Williams, M.M.; Stanford, J.C.; Balko, J.M.; Young, C.; Kuba, M.G.; Sanchez, V.; Williams, A.J.; Hicks, D.J.; et al. ErbB3 downregulation enhances luminal breast tumor response to antiestrogens. J. Clin. Investig. 2013, 123, 4329-4343. [CrossRef] [PubMed]

87. Zhang, N.; Chang, Y.; Rios, A.; An, Z. HER3/ErbB3, an emerging cancer therapeutic target. Acta Biochim. Biophys. Sin. 2016, 48, 39-48. [CrossRef] [PubMed]

88. US National Institutes of Health. Available online: http://www.clinicaltrials.gov/ (accessed on 1 November 2016).

89. Bos, P.D.; Zhang, X.H.F.; Nadal, C.; Shu, W.; Gomis, R.R.; Nguyen, D.X.; Minn, A.J.; van de Vijver, M.J.; Gerald, W.L.; Foekens, J.A.; et al. Genes that mediate breast cancer metastasis to the brain. Nature 2009, 459, 1005-1009. [CrossRef] [PubMed] 
90. Ding, L.; Ellis, M.J.; Li, S.; Larson, D.E.; Chen, K.; Wallis, J.W.; Harris, C.C.; McLellan, M.D.; Fulton, R.S.; Fulton, L.L.; et al. Genome remodelling in a basal-like breast cancer metastasis and xenograft. Nature 2010, 464, 999-1005. [CrossRef] [PubMed]

91. McMullin, R.P.; Wittner, B.S.; Yang, C.; Denton-Schneider, B.R.; Hicks, D.; Singavarapu, R.; Moulis, S.; Lee, J.; Akbari, M.R.; Narod, S.A.; et al. A BRCA1 deficient-like signature is enriched in breast cancer brain metastases and predicts DNA damage-induced poly (ADP-ribose) polymerase inhibitor sensitivity. Breast Cancer Res. 2014, 16, 25. [CrossRef] [PubMed]

92. Bollig-Fischer, A.; Michelhaugh, S.K.; Wijesinghe, P.; Dyson, G.; Kruger, A.; Palanisamy, N.; Choi, L.; Alosh, B.; Ali-Fehmi, R.; Mittal, S. Cytogenomic profiling of breast cancer brain metastases reveals potential for repurposing targeted therapeutics. Oncotarget 2015, 6, 14614-14624. [CrossRef] [PubMed]

93. Brastianos, P.K.; Carter, S.L.; Santagata, S.; Cahill, D.P.; Taylor-Weiner, A.; Jones, R.T.; van Allen, E.M.; Lawrence, M.S.; Horowitz, P.M.; Cibulskis, K.; et al. Genomic Characterization of Brain Metastases Reveals Branched Evolution and Potential Therapeutic Targets. Cancer Discov. 2015, 5, 1164-1177. [CrossRef] [PubMed]

94. Lee, J.Y.; Park, K.; Lim, S.H.; Kim, H.S.; Yoo, K.H.; Jung, K.S.; Song, H.N.; Hong, M.; Do, I.G.; Ahn, T.; et al. Mutational profiling of brain metastasis from breast cancer: Matched pair analysis of targeted sequencing between brain metastasis and primary breast cancer. Oncotarget 2015, 6, 43731-43742. [PubMed]

95. Varešlija, D.; Fagan, A.; Buckley, P.; Farrell, M.; Hill, A.; Young, L. Whole genome transcriptome analysis of sequential breast to brain metastasis uncovers new signalling pathways and druggable targets. Cancer Res. 2016, 76, P20503. [CrossRef]

96. Lee, J.Y.; Park, K.; Lee, E.; Ahn, T.; Jung, H.H.; Lim, S.H.; Hong, M.; Do, I.G.; Cho, E.Y.; Kim, D.H.; et al. Gene Expression Profiling of Breast Cancer Brain Metastasis. Sci. Rep. 2016, 6, 28623. [CrossRef] [PubMed]

97. Zhang, S.; Huang, W.C.; Zhang, L.; Zhang, C.; Lowery, F.J.; Ding, Z.; Guo, H.; Wang, H.; Huang, S.; Sahin, A.A.; et al. SRC family kinases as novel therapeutic targets to treat breast cancer brain metastases. Cancer Res. 2013, 73, 5764-5774. [CrossRef] [PubMed]

98. Palmieri, D.; Bronder, J.L.; Herring, J.M.; Yoneda, T.; Weil, R.J.; Stark, A.M.; Kurek, R.; Vega-Valle, E.; Feigenbaum, L.; Halverson, D.; et al. Her-2 overexpression increases the metastatic outgrowth of breast cancer cells in the brain. Cancer Res. 2007, 67, 4190-4198. [CrossRef] [PubMed]

99. Fitzgerald, D.P.; Subramanian, P.; Deshpande, M.; Graves, C.; Gordon, I.; Qian, Y.; Snitkovsky, Y.; Liewehr, D.J.; Steinberg, S.M.; Paltan-Ortiz, J.D.; et al. Opposing effects of pigment epithelium-derived factor on breast cancer cell versus neuronal survival: Implication for brain metastasis and metastasis-induced brain damage. Cancer Res. 2012, 72, 144-153. [CrossRef] [PubMed]

100. Jacob, L.S.; Vanharanta, S.; Obenauf, A.C.; Pirun, M.; Viale, A.; Socci, N.D.; Massague, J. Metastatic Competence Can Emerge with Selection of Preexisting Oncogenic Alleles without a Need of New Mutations. Cancer Res. 2015, 75, 3713-3719. [CrossRef] [PubMed]

101. Laimito, K.R.; Gamez-Pozo, A.; Sepulveda, J.; Manso, L.; Lopez-Vacas, R.; Pascual, T.; Fresno Vara, J.A.; Ciruelos, E. Characterisation of the triple negative breast cancer phenotype associated with the development of central nervous system metastases. Ecancermedicalscience 2016, 10, 632. [PubMed]

102. Drolez, A.; Vandenhaute, E.; Delannoy, C.P.; Dewald, J.H.; Gosselet, F.; Cecchelli, R.; Julien, S.; Dehouck, M.P.; Delannoy, P.; Mysiorek, C. ST6GALNAC5 Expression Decreases the Interactions between Breast Cancer Cells and the Human Blood-Brain Barrier. Int. J. Mol. Sci. 2016, 17, 1309. [CrossRef] [PubMed]

103. Vargo-Gogola, T.; Rosen, J.M. Modelling breast cancer: One size does not fit all. Nat. Rev. Cancer 2007, 7, 659-672. [CrossRef]

104. Cancer Genome Atlas, N. Comprehensive molecular portraits of human breast tumours. Nature 2012, 490, 61-70.

105. Ciriello, G.; Gatza, M.L.; Beck, A.H.; Wilkerson, M.D.; Rhie, S.K.; Pastore, A.; Zhang, H.; McLellan, M.; Yau, C.; Kandoth, C.; et al. Comprehensive Molecular Portraits of Invasive Lobular Breast Cancer. Cell 2015, 163, 506-519. [CrossRef] [PubMed]

106. Nik-Zainal, S.; Davies, H.; Staaf, J.; Ramakrishna, M.; Glodzik, D.; Zou, X.; Martincorena, I.; Alexandrov, L.B.; Martin, S.; Wedge, D.C.; et al. Landscape of somatic mutations in 560 breast cancer whole-genome sequences. Nature 2016, 534, 47-54. [CrossRef] [PubMed] 
107. Berghoff, A.S.; Magerle, M.; Ilhan-Mutlu, A.; Dinhof, C.; Widhalm, G.; Dieckman, K.; Marosi, C.; Wohrer, A.; Hackl, M.; Zochbauer-Muller, S.; et al. Frequent overexpression of ErbB—Receptor family members in brain metastases of non-small cell lung cancer patients. Acta Pathol. Microbiol. Immunol. Scand. 2013, 121, 144-152. [CrossRef] [PubMed]

108. Sun, M.; Behrens, C.; Feng, L.; Ozburn, N.; Tang, X.; Yin, G.; Komaki, R.; Varella-Garcia, M.; Hong, W.K.; Aldape, K.D.; et al. HER family receptor abnormalities in lung cancer brain metastases and corresponding primary tumors. Clin. Cancer Res. 2009, 15, 4829-4837. [CrossRef] [PubMed]

109. Palmieri, D.; Fitzgerald, D.; Shreeve, S.M.; Hua, E.; Bronder, J.L.; Weil, R.J.; Davis, S.; Stark, A.M.; Merino, M.J.; Kurek, R.; et al. Analyses of resected human brain metastases of breast cancer reveal the association between up-regulation of hexokinase 2 and poor prognosis. Mol. Cancer Res. 2009, 7, 1438-1445. [CrossRef] [PubMed]

110. Owonikoko, T.K.; Arbiser, J.; Zelnak, A.; Shu, H.K.; Shim, H.; Robin, A.M.; Kalkanis, S.N.; Whitsett, T.G.; Salhia, B.; Tran, N.L.; et al. Current approaches to the treatment of metastatic brain tumours. Nat. Rev. Clin. Oncol. 2014, 11, 203-222. [CrossRef] [PubMed]

111. Maher, E.A.; Mietz, J.; Arteaga, C.L.; de Pinho, R.A.; Mohla, S. Brain metastasis: Opportunities in basic and translational research. Cancer Res. 2009, 69, 6015-6020. [CrossRef] [PubMed]

112. Burvenich, I.J.; Lee, F.T.; Cartwright, G.A.; O’Keefe, G.J.; Makris, D.; Cao, D.; Gong, S.; Chueh, A.C.; Mariadason, J.M.; Brechbiel, M.W.; et al. Molecular imaging of death receptor 5 occupancy and saturation kinetics in vivo by humanized monoclonal antibody CS-1008. Clin. Cancer Res. 2013, 19, 5984-5993. [CrossRef] [PubMed]

113. Swain, S.M.; Baselga, J.; Miles, D.; Im, Y.H.; Quah, C.; Lee, L.F.; Cortes, J. Incidence of central nervous system metastases in patients with HER2-positive metastatic breast cancer treated with pertuzumab, trastuzumab, and docetaxel: Results from the randomized phase III study CLEOPATRA. Ann. Oncol. 2014, 25, 1116-1121. [CrossRef] [PubMed]

114. Lin, N.U.; Amiri-Kordestani, L.; Palmieri, D.; Liewehr, D.J.; Steeg, P.S. CNS metastases in breast cancer: Old challenge, new frontiers. Clin. Cancer Res. 2013, 19, 6404-6418. [CrossRef] [PubMed]

115. Preusser, M.; Winkler, F.; Collette, L.; Haller, S.; Marreaud, S.; Soffietti, R.; Klein, M.; Reijneveld, J.C.; Tonn, J.C.; Baumert, B.G.; et al. Trial design on prophylaxis and treatment of brain metastases: Lessons learned from the EORTC Brain Metastases Strategic Meeting 2012. Eur. J. Cancer 2012, 48, 3439-3447. [CrossRef] [PubMed]

116. Kim, S.J.; Kim, J.S.; Park, E.S.; Lee, J.S.; Lin, Q.; Langley, R.R.; Maya, M.; He, J.; Kim, S.W.; Weihua, Z.; et al. Astrocytes upregulate survival genes in tumor cells and induce protection from chemotherapy. Neoplasia 2011, 13, 286-298. [CrossRef] [PubMed]

117. Fidler, I.J.; Balasubramanian, K.; Lin, Q.; Kim, S.W.; Kim, S.J. The brain microenvironment and metastasis. Mol. Cells 2010, 30, 93-98. [CrossRef] [PubMed]

118. Kaplan, M.A.; Ertugrul, H.; Firat, U.; Kucukoner, M.; Inal, A.; Urakci, Z.; Pekkolay, Z.; Isikdogan, A. Brain metastases in HER2-positive metastatic breast cancer patients who received chemotherapy with or without trastuzumab. Breast Cancer 2015, 22, 503-509. [CrossRef] [PubMed]

119. Nahas, G.; Bliss, S.A.; Sinha, G.; Ganta, T.; Greco, S.J.; Rameshwar, P. Is reduction of tumor burden sufficient for the 21st century? Cancer Lett. 2015, 356, 149-155. [CrossRef] [PubMed]

120. Benjamin, L.; Cotte, F.E.; Mercier, F.; Vainchtock, A.; Vidal-Trecan, G.; Durand-Zaleski, I. Burden of breast cancer with brain metastasis: A French national hospital database analysis. J. Med. Econ. 2012, 15, 493-499. [CrossRef] [PubMed]

121. Koay, E.; Sulman, E.P. Management of brain metastasis: Past lessons, modern management, and future considerations. Curr. Oncol. Rep. 2012, 14, 70-78. [CrossRef] [PubMed]

122. Miller, K.D.; Weathers, T.; Haney, L.G.; Timmerman, R.; Dickler, M.; Shen, J.; Sledge, G.W., Jr. Occult central nervous system involvement in patients with metastatic breast cancer: Prevalence, predictive factors and impact on overall survival. Ann. Oncol. 2003, 14, 1072-1077. [CrossRef] [PubMed]

123. Cummings, M.C.; Simpson, P.T.; Reid, L.E.; Jayanthan, J.; Skerman, J.; Song, S.; McCart Reed, A.E.; Kutasovic, J.R.; Morey, A.L.; Marquart, L.; et al. Metastatic progression of breast cancer: Insights from 50 years of autopsies. J. Pathol. 2014, 232, 23-31. [CrossRef] [PubMed]

124. Lee, Y.T. Breast carcinoma: Pattern of metastasis at autopsy. J. Surg. Oncol. 1983, 23, 175-180. [CrossRef] [PubMed]

125. Tsukada, Y.; Fouad, A.; Pickren, J.W.; Lane, W.W. Central nervous system metastasis from breast carcinoma: Autopsy study. Cancer 1983, 52, 2349-2354. [CrossRef] 
126. Murrell, D.H.; Foster, P.J.; Chambers, A.F. Brain metastases from breast cancer: Lessons from experimental magnetic resonance imaging studies and clinical implications. J. Mol. Med. 2014, 92, 5-12. [CrossRef] [PubMed]

127. Kalita-de Croft, P.; Al-Ejeh, F.; McCart Reed, A.E.; Saunus, J.M.; Lakhani, S.R. Omics Approaches in Breast Cancer Research and Clinical Practice. Adv. Anat. Pathol. 2016, 23, 356-367. [CrossRef] [PubMed]

128. Lin, N.U.; Bellon, J.R.; Winer, E.P. CNS metastases in breast cancer. J. Clin. Oncol. 2004, 22, 3608-3617. [CrossRef] [PubMed]

129. Carmeliet, P.; Jain, R.K. Principles and mechanisms of vessel normalization for cancer and other angiogenic diseases. Nat. Rev. Drug Discov. 2011, 10, 417-427. [CrossRef] [PubMed]

130. Monsky, W.L.; Mouta Carreira, C.; Tsuzuki, Y.; Gohongi, T.; Fukumura, D.; Jain, R.K. Role of host microenvironment in angiogenesis and microvascular functions in human breast cancer xenografts: Mammary fat pad versus cranial tumors. Clin. Cancer Res. 2002, 8, 1008-1013. [PubMed]

131. Moeller, B.J.; Richardson, R.A.; Dewhirst, M.W. Hypoxia and radiotherapy: Opportunities for improved outcomes in cancer treatment. Cancer Metastasis Rev. 2007, 26, 241-248. [CrossRef] [PubMed]

132. Milojkovic Kerklaan, B.; van Tellingen, O.; Huitema, A.D.; Beijnen, J.H.; Boogerd, W.; Schellens, J.H.; Brandsma, D. Strategies to target drugs to gliomas and CNS metastases of solid tumors. J. Neurol. 2016, 263, 428-440. [CrossRef] [PubMed]

133. Jain, R.K.; Tong, R.T.; Munn, L.L. Effect of vascular normalization by antiangiogenic therapy on interstitial hypertension, peritumor edema, and lymphatic metastasis: Insights from a mathematical model. Cancer Res. 2007, 67, 2729-2735. [CrossRef] [PubMed]

134. Kobus, T.; Zervantonakis, I.K.; Zhang, Y.; McDannold, N.J. Growth inhibition in a brain metastasis model by antibody delivery using focused ultrasound-mediated blood-brain barrier disruption. J. Control. Release 2016, 238, 281-288. [CrossRef] [PubMed]

135. Alkins, R.; Burgess, A.; Ganguly, M.; Francia, G.; Kerbel, R.; Wels, W.S.; Hynynen, K. Focused ultrasound delivers targeted immune cells to metastatic brain tumors. Cancer Res. 2013, 73, 1892-1899. [CrossRef] [PubMed]

136. Li, J.; Cai, P.; Shalviri, A.; Henderson, J.T.; He, C.; Foltz, W.D.; Prasad, P.; Brodersen, P.M.; Chen, Y.; da Costa, R.; et al. A multifunctional polymeric nanotheranostic system delivers doxorubicin and imaging agents across the blood-brain barrier targeting brain metastases of breast cancer. ACS Nano 2014, 8, 9925-9940. [CrossRef] [PubMed]

137. Mittapalli, R.K.; Liu, X.; Adkins, C.E.; Nounou, M.I.; Bohn, K.A.; Terrell, T.B.; Qhattal, H.S.; Geldenhuys, W.J.; Palmieri, D.; Steeg, P.S.; et al. Paclitaxel-hyaluronic nanoconjugates prolong overall survival in a preclinical brain metastases of breast cancer model. Mol. Cancer Ther. 2013, 12, 2389-2399. [CrossRef] [PubMed]

138. Hamilton, A.M.; Aidoudi-Ahmed, S.; Sharma, S.; Kotamraju, V.R.; Foster, P.J.; Sugahara, K.N.; Ruoslahti, E.; Rutt, B.K. Nanoparticles coated with the tumor-penetrating peptide iRGD reduce experimental breast cancer metastasis in the brain. J. Mol. Med. 2015, 93, 991-1001. [CrossRef] [PubMed]

139. Patil, R.; Ljubimov, A.V.; Gangalum, P.R.; Ding, H.; Portilla-Arias, J.; Wagner, S.; Inoue, S.; Konda, B.; Rekechenetskiy, A.; Chesnokova, A.; et al. MRI virtual biopsy and treatment of brain metastatic tumors with targeted nanobioconjugates: Nanoclinic in the brain. ACS Nano 2015, 9, 5594-5608. [CrossRef] [PubMed]

140. Obenauf, A.C.; Zou, Y.; Ji, A.L.; Vanharanta, S.; Shu, W.; Shi, H.; Kong, X.; Bosenberg, M.C.; Wiesner, T.; Rosen, N.; et al. Therapy-induced tumour secretomes promote resistance and tumour progression. Nature 2015, 520, 368-372. [CrossRef] [PubMed]

141. Berghoff, A.S.; Preusser, M. The inflammatory microenvironment in brain metastases: Potential treatment target? Chin. Clin. Oncol. 2015, 4, 21. [PubMed]

142. Beham, H.S. Hercules Slaying the Hydra. Available online: https://de.wikipedia.org/wiki/Datei:Hercules_ slaying_the_Hydra.jpg (accessed on 1 November 2016).

(C) 2017 by the authors; licensee MDPI, Basel, Switzerland. This article is an open access article distributed under the terms and conditions of the Creative Commons Attribution (CC-BY) license (http:/ / creativecommons.org/licenses/by/4.0/). 